\title{
Changes in net ecosystem productivity and greenhouse gas exchange with fertilization of Douglas fir: Mathematical modeling in ecosys
}

\author{
R. F. Grant, ${ }^{1}$ T. A. Black, ${ }^{2}$ R. S. Jassal, ${ }^{2}$ and C. Bruemmer ${ }^{2}$ \\ Received 6 July 2009; revised 19 November 2009; accepted 1 April 2010; published 8 October 2010.
}

[1] The application of nitrogen fertilizers to Douglas fir forests is known to raise net ecosystem productivity (NEP), but also $\mathrm{N}_{2} \mathrm{O}$ emissions, the $\mathrm{CO}_{2}$ equivalent of which may offset gains in NEP when accounting for net greenhouse gas (GHG) exchange. However, total changes in NEP and $\mathrm{N}_{2} \mathrm{O}$ emissions caused by fertilizer between times of application and harvest, while needed for national GHG inventories, are difficult to quantify except through modeling. In this study, integrated hypotheses for soil and plant $\mathrm{N}$ processes within the ecosystem model ecosys were tested against changes in $\mathrm{CO}_{2}$ and $\mathrm{N}_{2} \mathrm{O}$ fluxes recorded with eddy covariance (EC) and surface flux chambers for 1 year after applying $20 \mathrm{~g} \mathrm{~N} \mathrm{~m}^{-2}$ of urea to a mature Douglas fir stand in British Columbia. Parameters from annual regressions of hourly modeled versus measured $\mathrm{CO}_{2}$ fluxes conducted before and after fertilization were unchanged $\left(b=1.0, R^{2}=0.8\right.$, RMSD $=$ $3.4 \mu \mathrm{mol} \mathrm{m} \mathrm{m}^{-2} \mathrm{~s}^{-1}$ ), indicating that model hypotheses for soil and plant $\mathrm{N}$ processes did not introduce bias into $\mathrm{CO}_{2}$ fluxes modeled after fertilization. These model hypotheses were then used to project changes in NEP and GHG exchange attributed to the fertilizer during the following 10 years until likely harvest of the Douglas fir stand. Increased $\mathrm{CO}_{2}$ uptake caused modeled and EC-derived annual NEP to rise from 443 and $386 \mathrm{~g} \mathrm{C} \mathrm{m}^{-2}$ in the year before fertilization to 591 and $547 \mathrm{~g} \mathrm{C} \mathrm{m}^{-2}$ in the year after. These gains contributed to a sustained rise in modeled wood $\mathrm{C}$ production with fertilization, which was partly offset by a decline in soil $\mathrm{C}$ attributed in the model to reduced root $\mathrm{C}$ productivity and litterfall. Gains in net $\mathrm{CO}_{2}$ uptake were further offset in the model by a rise of $0.74 \mathrm{~g} \mathrm{~N} \mathrm{~m}^{-2} \mathrm{yr}^{-1}$ in $\mathrm{N}_{2} \mathrm{O}$ emissions during the first year after fertilization, which was consistent with one of $1.05 \mathrm{~g} \mathrm{~N} \mathrm{~m}^{-2} \mathrm{yr}^{-1}$ estimated from surface flux chamber measurements. Further $\mathrm{N}_{2} \mathrm{O}$ emissions were neither modeled nor measured after the first year. At the end of the 11 year model projection, a total $\mathrm{C}$ sequestration of $1045 \mathrm{~g} \mathrm{C} \mathrm{m}^{-2}$ was attributed to the $20 \mathrm{~g} \mathrm{~N} \mathrm{~m}^{-2}$ of fertilizer. However, only $119 \mathrm{~g} \mathrm{C} \mathrm{m}^{-2}$ of this was sequestered in stocks that would remain on site after harvest (foliage, root, litter, soil). The remainder was sequestered as harvested wood, the duration of which would depend on use of the wood product. The direct and indirect $\mathrm{CO}_{2}$-equivalent costs of this application, including $\mathrm{N}_{2} \mathrm{O}$ emission, were estimated to offset almost all non-harvested $\mathrm{C}$ sequestration attributed to the fertilizer.

Citation: Grant, R. F., T. A. Black, R. S. Jassal, and C. Bruemmer (2010), Changes in net ecosystem productivity and greenhouse gas exchange with fertilization of Douglas fir: Mathematical modeling in ecosys, J. Geophys. Res., 115, G04009, doi:10.1029/2009JG001094.

\section{Introduction}

[2] Most temperate and boreal forest ecosystems are considered to be nitrogen limited, so that $\mathrm{N}$ fertilizer

\footnotetext{
${ }^{1}$ Department of Renewable Resources, University of Alberta, Edmonton, Alberta, Canada.

${ }^{2}$ Biometeorology and Soil Physics Group, Faculty of Land and Food Systems, University of British Columbia, Vancouver, British Columbia, Canada.

Copyright 2010 by the American Geophysical Union. 0148-0227/10/2009JG001094
}

application may increase forest $\mathrm{CO}_{2}$ uptake and consequent C storage [Aber et al., 1989; Johnson and Curtis, 2001], slowing the rise in atmospheric $\mathrm{CO}_{2}$ concentration and increasing wood supply. However, $\mathrm{N}$ fertilizer production involves the emission of $\mathrm{CO}_{2}$, and its application may also increase emission of $\mathrm{N}_{2} \mathrm{O}$ [Jassal et al., 2008; Matson et al., 1992; Sitaula et al., 1995b], an important greenhouse gas (GHG). These emissions offset the effects of increased $\mathrm{CO}_{2}$ uptake on net GHG exchange and thereby on the radiative properties of the atmosphere thought to drive climate change. Therefore, a full accounting of net GHG exchange 


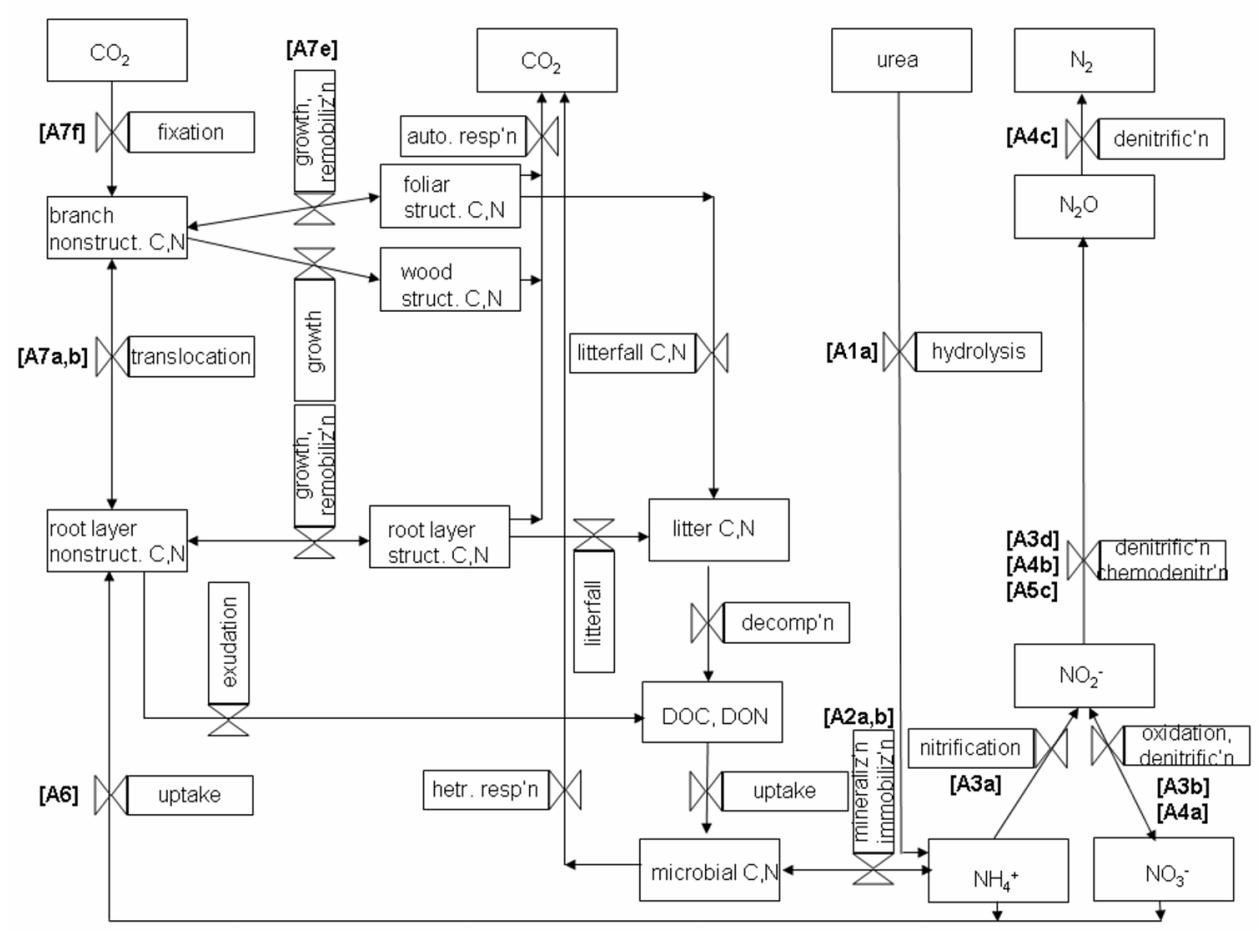

Figure 1. Conceptual model of key $\mathrm{C}$ and $\mathrm{N}$ transfers in ecosys. Numbers in brackets refer to equations in Appendix A.

from fertilizer application in forests needs to include effects on net $\mathrm{CO}_{2}$ uptake by trees as well as on $\mathrm{CO}_{2}$ and $\mathrm{N}_{2} \mathrm{O}$ emissions from $\mathrm{N}$ fertilizer production and application.

[3] Gains in net $\mathrm{CO}_{2}$ uptake from fertilization of forest stands are thought to be caused by root uptake and rootshoot transfer of fertilizer $\mathrm{N}$, resulting in increased foliar $\mathrm{N}$ concentrations that raise photosynthetic capacity and hence $\mathrm{CO}_{2}$ fixation for several years after application [Hopmans and Chappell, 1994]. However, these gains are highly variable because they are affected by the biochemical and hydrologic characteristics of the fertilized stands. Gains may be smaller with lower $\mathrm{C} / \mathrm{N}$ ratios in tree foliage or the soil LFH layer when $\mathrm{N}$ limitations are less severe [Edmonds and Hsiang, 1987; Hopmans and Chappell, 1994]. Gains may also be smaller when uptake of fertilizer $\mathrm{N}$ is reduced by rapid nitrification of fertilizer products [Matson et al., 1992] and subsequent leaching of nitrate [Flint et al., 2008].

[4] Gains in net $\mathrm{CO}_{2}$ uptake from fertilization are also affected by changes in $\mathrm{C}$ allocation to organs with differing turnover rates within trees. With improved $\mathrm{N}$ supply, trees typically allocate more resources to shoot growth, much of it in boles with slower turnover, than to root growth with more rapid turnover. This reallocation is based on a theory of functional equilibrium between shoots and roots in which nutrient allocation is based on proximity to sites of acquisition and on rates of consumption [Ericsson et al., 1996]. Reduced root allocation is consistent with reduced soil respiration frequently measured in fertilized forest stands [Giardina et al., 2004; Olsson et al., 2005]. Changes in root-shoot allocation with fertilization have been shown in coniferous seedlings [e.g., Iivonen et al., 2001; Kaakinen et al., 2004]; however, evidence for such changes in mature stands remains inconclusive. Iivonen et al. [2006] found small decreases in allocation of $\mathrm{C}$ and $\mathrm{N}$ to fine roots with fertilization, but little change in allocation of $\mathrm{C}$ and $\mathrm{N}$ to aboveground organs or coarse roots in spite of a large increase in growth. Earlier studies have found both increases and no changes in allocation to roots with fertilization. In a further complication, some studies have indicated that improved N supply causes shoot growth to be allocated more to foliage and branches with more rapid turnover than to boles with slower turnover [Gower et al., 1992; Valinger, 1993]. These changes in allocation require that gains in net $\mathrm{CO}_{2}$ uptake and $\mathrm{C}$ storage attributed to fertilization be evaluated in comprehensive ecosystem studies rather than from simple estimates of gains in wood $\mathrm{C}$.

[5] Increases in $\mathrm{N}_{2} \mathrm{O}$ emissions from fertilization of forest stands are thought to be caused by nitrification and denitrification of fertilizer $\mathrm{N}$ and its mineral products [Martikainen and de Boer, 1993; Matson et al., 1992]. $\mathrm{N}_{2} \mathrm{O}$ emissions from nitrification are known to be favored by low $\mathrm{pH}$ found in acidic forest floors that develop under coniferous stands [Martikainen and de Boer, 1993; Sitaula et al., 1995b], suggesting that these emissions may be supplemented by chemodenitrification [e.g., Mørkved et al., 2007]. Estimates of $\mathrm{N}_{2} \mathrm{O}$ emissions derived from surface flux measurements in forests are highly variable. Although these emissions are thought to be small [Matson et al., 1992], the growing use of $\mathrm{N}$ fertilizer may cause them to rise. Jassal et al. [2008] measured substantial $\mathrm{N}_{2} \mathrm{O}$ emissions (5\% of added N) during several months after a fertilizing a Douglas fir stand in British Columbia, although other researchers have measured less (e.g., $0.5 \%$ by Sitaula et al. [1995b] during 1 month after fertilizing Scots pine, $0.35 \%$ by Matson et al. [1992] during a growing season after fertilizing Douglas fir, and $0.2 \%$ by Bowden et al. [1991] during 1 year after 
fertilizing in red pine). However, even small emissions of $\mathrm{N}_{2} \mathrm{O}$ could partially offset gains in $\mathrm{CO}_{2}$ uptake when estimating net $\mathrm{GHG}$ exchange from $\mathrm{N}$ fertilizer application.

[6] The variability and duration of changes in $\mathrm{CO}_{2}$ and $\mathrm{N}_{2} \mathrm{O}$ exchange caused by fertilizer $\mathrm{N}$ application in different forest stands complicate efforts in GHG accounting for fertilizer use directly from site studies. Such accounting could benefit from mathematical models based on a comprehensive set of integrated hypotheses for the biological and physical processes driving changes in GHG exchange. In this study, integrated hypotheses for soil and plant $\mathrm{N}$ processes within the detailed ecosystem model ecosys are tested against changes in $\mathrm{CO}_{2}$ and $\mathrm{N}_{2} \mathrm{O}$ fluxes recorded with eddy covariance (EC) and surface flux chambers during the first year after applying $20 \mathrm{~g} \mathrm{~N} \mathrm{~m}^{-2}$ of urea to a mature Douglas fir stand near Campbell River in British Columbia. These hypotheses are then used to project changes in GHG exchange and in $\mathrm{C}$ and $\mathrm{N}$ storage from this application during the following 10 years until the likely harvest of the stand.

\section{Model Development}

\subsection{General Overview}

[7] Key algorithms for $\mathrm{C}$ and $\mathrm{N}$ transformations that drive ecosystem productivity and greenhouse gas exchange in ecosys are described in detail elsewhere [Grant and Flanagan, 2007; Grant et al., 1993a, 1993b, 2005, 2006a, 2006b, 2006c, 2007a, 2007b, 2007c; Grant, 2004; Grant and Pattey, 2003]. Algorithms that directly govern the transformation, uptake, and assimilation of fertilizer $\mathrm{N}$ are described in summary form below with reference to equations and definitions listed in Appendix A and represented in Figure 1.

\subsection{Urea Hydrolysis}

[8] Urea fertilizer first undergoes hydrolysis to $\mathrm{NH}_{3}$ (equation (A1a)) at rates calculated as the product of specific hydrolysis activity and total microbial $\mathrm{C}$ (as a proxy for urease), constrained by an Arrhenius function of soil temperature [Moyo et al., 1989; Vlek and Carter, 1983] and a Michaelis-Menten function of urea concentration [Lal et al., 1993] incorporating a competitive inhibition term driven by soil water content to simulate effects of soil drying [Vlek and Carter, 1983]. The hydrolysis product $\mathrm{NH}_{3}$ is maintained in equilibrium with $\mathrm{NH}_{4}^{+}$according to soil or residue $\mathrm{pH}$ (equation (A1b), in which states they undergo other reactions described below.

\subsection{Mineralization-Immobilization}

[9] Each kinetic component $j$ ( $j$ is labile or resistant) of each microbial population $m$ ( $m$ is obligately aerobic bacteria, obligately aerobic fungi, facultatively anaerobic denitrifiers, anaerobic fermenters plus $\mathrm{H}_{2}$-producing acetogens, acetotrophic methanogens, hydrogenotrophic methanogens and methanotrophs, $\mathrm{NH}_{3}$ and $\mathrm{NO}_{2}^{-}$oxidizers, and nonsymbiotic diazotrophs) in each substrate-microbe complex $i$ ( $i$ is coarse woody residue, fine nonwoody residue, particulate organic matter, or humus) in the surface residue and each soil layer $l$ seeks to maintain a set population-specific $\mathrm{C} / \mathrm{N}$ ratio by mineralizing $\mathrm{NH}_{4}^{+}$(equation (A2a)) or by immobilizing $\mathrm{NH}_{4}^{+}$(equation (A2b)) or $\mathrm{NO}_{3}^{-}$(equation (A2c)).
Changes in microbial $\mathrm{C}$ and $\mathrm{N}$ arise from changes in organic substrate availability and quality and in soil temperature and water content. Provision is made for $\mathrm{C} / \mathrm{N}$ ratios to rise above set values during immobilization but at a cost to microbial function. Under these conditions, provision is also made for internal recycling of microbial N. These transformations control the exchange of $\mathrm{N}$ between organic and inorganic states in soil. Equations representing these transformations are given in greater detail by Grant et al. [1993a, 1993b].

\subsection{Nitrification}

[10] Rates of $\mathrm{NH}_{3}$ and $\mathrm{NO}_{2}^{-}$oxidation are calculated from specific $\mathrm{NH}_{3}$ or $\mathrm{NO}_{2}^{-}$oxidizer activities multiplied by $\mathrm{NH}_{3}$ or $\mathrm{NO}_{2}^{-}$oxidizer biomasses, constrained by an Arrhenius function of soil temperature and Michaelis-Menten functions of aqueous $\mathrm{NH}_{3}$ [Stark and Firestone, 1996] or $\mathrm{NO}_{2}^{-}$ [Blackburne et al., 2007] concentrations and aqueous $\mathrm{CO}_{2}$ concentrations (equations (A3a) and (A3b)). Rates of $\mathrm{NO}_{2}^{-}$ oxidation are inhibited by aqueous $\mathrm{NH}_{3}$ and $\mathrm{HNO}_{2}$ concentrations [Blackburne et al., 2007] (equation (A3c)). Reduction of $\mathrm{NO}_{2}^{-}$to $\mathrm{N}_{2} \mathrm{O}$ by nitrifiers (equation (A3d)) is driven from demand for electron acceptors to oxidize $\mathrm{NH}_{3}$ (equation (A3a)) unmet by $\mathrm{O}_{2}$ because of diffusion limitations, and is constrained by Michaelis-Menten functions of aqueous $\mathrm{NO}_{2}^{-}$and $\mathrm{CO}_{2}$. Equations for these processes are given in greater detail by Grant et al. [2006b].

\subsection{Biological Denitrification}

[11] Demand for electron acceptors from denitrifier $\mathrm{C}$ oxidation unmet by $\mathrm{O}_{2}$ because of diffusion limitations [Grant et al., 2006b] drives the sequential reduction of $\mathrm{NO}_{3}^{-}$, $\mathrm{NO}_{2}^{-}$, and $\mathrm{N}_{2} \mathrm{O}$, constrained by Michaelis-Menten function of $\mathrm{NO}_{3}^{-}, \mathrm{NO}_{2}^{-}$, and $\mathrm{N}_{2} \mathrm{O}$ concentrations [Yoshinari et al., 1977] (equations (A4a), (A4b), and (A4c)). All gaseous products undergo convective-dispersive transfer and aqueous and gaseous phases. Equations for these processes are given in greater detail by Grant et al. [2006b].

\subsection{Chemodenitrification}

[12] $\mathrm{NO}_{2}^{-}$from nitrification and denitrification is in dynamic equilibrium with $\mathrm{HNO}_{2}$ depending on soil or residue $\mathrm{pH}$ (equation (A5a)). $\mathrm{HNO}_{2}$ concentration drives firstorder decomposition [Cleemput and Samater, 1996] (equation (A5b)) to $\mathrm{N}_{2} \mathrm{O}$ [Mørkved et al., 2007] (equation (A5c)) and other N products [Cleemput and Samater, 1996].

\subsection{Root and Mycorrhizal Uptake}

[13] $\mathrm{NH}_{4}^{+}$and $\mathrm{NO}_{3}^{-}$uptake by roots and mycorrhizae is calculated from mass flow plus radial diffusion through soil between adjacent roots and mycorrhizae (equations (A6a) and $(\mathrm{A} 6 \mathrm{c})$ ) coupled with active uptake at root and mycorrhizal surfaces (equations (A6b) and (A6d)) in multilayered soil profiles. Both fluxes depend on root length density derived from a root growth model, as described in greater detail by Grant [1998]. Uptake products in each soil layer are added to nonstructural $\mathrm{N}$ pools in roots and mycorrhizae. If $\mathrm{N} / \mathrm{C}$ ratios of these nonstructural pools rise above those required for growth, inhibition of root and mycorrhizal $\mathrm{N}$ uptake is invoked to keep uptake in balance with $\mathrm{CO}_{2}$ fixation [Grant, 1998]. 
Table 1. Key Properties of the Quimper Sandy Loam Near Campbell River ${ }^{\mathrm{a}}$

\begin{tabular}{lllllll}
\hline \multicolumn{1}{c}{ Quimper Horizon } & LFH & Ahe & Bf & Bm & Bm & BCc \\
\hline Depth to Bottom (m) & 0.03 & 0.09 & 0.23 & 0.53 & 0.83 & 1.33 \\
Bulk Density $\left(\mathrm{Mg} \mathrm{m}^{-3}\right)$ & 0.1 & 1.3 & 1.5 & 1.5 & 1.5 & 1.9 \\
Field Capacity $\left(\mathrm{m}^{3} \mathrm{~m}^{-3}\right)$ & 0.21 & 0.21 & 0.21 & 0.19 & 0.13 & 0.10 \\
Wilting Point $\left(\mathrm{m}^{3} \mathrm{~m}^{-3}\right)$ & 0.14 & 0.08 & 0.08 & 0.06 & 0.04 & 0.03 \\
$K_{\text {sat }}\left(\mathrm{mm} \mathrm{h}^{-1}\right)$ & 210 & 10 & 10 & 100 & 100 & 1 \\
Sand $\left(\mathrm{g} \mathrm{kg}^{-1}\right)$ & 0 & 540 & 660 & 760 & 720 & 740 \\
Silt $\left(\mathrm{g} \mathrm{kg}^{-1}\right)$ & 0 & 380 & 270 & 220 & 250 & 240 \\
Clay $\left(\mathrm{g} \mathrm{kg}^{-1}\right)$ & 0 & 80 & 70 & 20 & 30 & 20 \\
Coarse Frag. $\left(\mathrm{m}^{3} \mathrm{~m}^{-3}\right)$ & 0 & 0.33 & 0.33 & 0.33 & 0.33 & 0.33 \\
CEC $\left(\mathrm{cmol} \mathrm{kg}^{-1}\right)$ & 124 & 20 & 10 & 9 & 10 & 9 \\
pH & 4.7 & 5.0 & 4.9 & 4.9 & 4.7 & 4.8 \\
Organic C $\left(\mathrm{g} \mathrm{kg}^{-1}\right)$ & 385 & 74 & 62 & 17 & 11 & 9 \\
Total N $\left(\mathrm{g} \mathrm{Mg}^{-1}\right)$ & 8100 & 2200 & 1900 & 850 & 750 & 720 \\
\hline
\end{tabular}

${ }^{\mathrm{a}}$ From Humphreys [2004] and Soil Landscapes of Canada v. 3.1.

\subsection{Plant Assimilation}

[14] Nonstructural N pools, generated from root and mycorrhizal uptake, are coupled with nonstructural $\mathrm{C}$ pools, generated from $\mathrm{CO}_{2}$ fixation, in mycorrhizae, roots, and branches. Transfers among these pools (equations (A7a) and (A7b)) are driven by concentration gradients generated by acquisition versus consumption of nonstructural $\mathrm{N}$ and $\mathrm{C}$ in mycorrhizae, roots, and branches [Grant, 1998] (equations $(\mathrm{A} 7 \mathrm{c})$ and $(\mathrm{A} 7 \mathrm{~d})$ ). Ratios of nonstructural $\mathrm{N}$ and $\mathrm{C}$ in branches govern $\mathrm{CO}_{2}$ fixation (equations $(\mathrm{A} 7 \mathrm{f}),(\mathrm{A} 7 \mathrm{~g})$, and (A7h)) [Farquhar et al., 1980] by (1) setting ratios of structural $\mathrm{N}$ and $\mathrm{C}$ in leaves (A7e) and hence maximum carboxylation rates (equations (A7i) and (A7j) and (2) determining rubisco activation through product inhibition (A7k). Nonstructural C pools also drive autotrophic respiration $\left(R_{\mathrm{a}}\right)$ to meet maintenance and growth requirements $\left(R_{\mathrm{m}}\right.$ and $\left.R_{\mathrm{g}}\right)$ [Grant et al., 2007c, equations (C12)-(C16)]. If $R_{\mathrm{a}}$ falls below $R_{\mathrm{m}}$, the deficit drives the withdrawal of remobilizable $\mathrm{C}$ and $\mathrm{N}$ from older leaves and supporting structures into $\mathrm{C}$ and $\mathrm{N}$ nonstructural pools, the former of which is used to sustain $R_{\mathrm{m}}$ and the latter of which can be translocated to newer foliage. All model equations for $\mathrm{C}$ and $\mathrm{N}$ are fully coupled to counterparts for phosphorus. Equations for these processes are given in greater detail by Grant et al. [2007c] and in earlier references cited therein.

\section{Field Experiment}

\subsection{Site Description}

[15] The field experiment was conducted in a stand dominated by Douglas fir (Pseudotsuga menziesii), but also including western red cedar (Thuja plicata), western hemlock (Tsuga heterophylla), and red alder (Alnus rubra). This stand started to regenerate in 1949 after fires and logging in 1939 and 1943 on a well-drained Humo-Ferric Podzol (Quimper sandy loam, Table 1) about $10 \mathrm{~km}$ southwest of Campbell River $\left(49^{\circ} 52^{\prime} 7.8^{\prime \prime} \mathrm{N}, 125^{\circ} 20^{\prime} 6.3^{\prime \prime} \mathrm{W}\right)$ on the east coast of Vancouver Island, Canada (mean annual temperature and precipitation: $8.6^{\circ} \mathrm{C}$ and $1450 \mathrm{~mm}$ ). This stand is further described in the works of Humphreys et al. [2006] and Morgenstern et al. [2004].

\subsection{Fertilizer Treatments}

[16] A 1115 ha area of the stand surrounding the eddy covariance (EC) flux tower was aerially fertilized with $200 \mathrm{~kg} \mathrm{~N} \mathrm{ha}^{-1}$ urea on 13 January 2007, following standard commercial practice. A 17 ha experimental area on the southeast side of the fertilized area remained unfertilized for a field plot study to measure changes in soil $\mathrm{N}_{2} \mathrm{O}$ emissions and in plant $\mathrm{C}$ and $\mathrm{N}$ stocks caused by fertilizer. Within this area, urea was applied manually at $200 \mathrm{~kg} \mathrm{~N} \mathrm{ha}^{-1}$ on 11 April 2007 to four of eight $100 \mathrm{~m}^{2}$ plots, while the remaining four plots remained unfertilized. In addition, eight $2 \mathrm{~m} \times 2 \mathrm{~m}$ plots, extended by $2 \mathrm{~m}$ wide buffers on each side, were established near the EC flux tower in August 2006 to measure changes in soil $\mathrm{CO}_{2}$ fluxes caused by fertilizer. These plots were protected from aerial fertilization on 13 January 2007, and then four were fertilized manually with urea at $200 \mathrm{~kg} \mathrm{~N}$ $\mathrm{ha}^{-1}$ on 31 January 2007. For both sets of plots, manual fertilizer application achieved the same fertilizer rate as that from the aerial application, but with greater uniformity required for chamber flux measurements.

\subsection{Site Measurements}

[17] Ecosystem $\mathrm{CO}_{2}$ and energy exchange have been measured by EC continuously since 1998 at a flux tower site (BC-DF49) within the fertilized area as described earlier [Jassal et al., 2007; Humphreys et al., 2006; Morgenstern et al., 2004]. Soil respiration $\left(R_{\mathrm{s}}\right)$ has been measured continuously since 2003 by one automated surface flux chamber near the flux tower. $R_{\mathrm{S}}$ measured with this chamber has been shown to represent well the spatial average of $R_{\mathrm{S}}$ for the stand [Jassal et al., 2007].

[18] Soil $\mathrm{N}_{2} \mathrm{O}$ effluxes were measured with a vented static chamber mounted on $21 \mathrm{~cm}$ diameter PVC collars installed in each $100 \mathrm{~m}^{2}$ plot within the 17 ha experimental area. $\mathrm{N}_{2} \mathrm{O}$ emissions from these plots were recorded every 2-3 weeks from fertilizer application on 11 April to the end of the year, and corroborated with emissions calculated from soil $\mathrm{N}_{2} \mathrm{O}$ concentration gradients [Jassal et al., 2008]. Soil $\mathrm{CO}_{2}$ effluxes were measured every 2-4 weeks using portable vented chambers mounted on two collars $(10 \mathrm{~cm}$ inner diameter, $4 \mathrm{~mm}$ wall thickness) in each $2 \mathrm{~m} \times 2 \mathrm{~m}$ plot near the flux tower, as described by Jassal et al. [2010]. Further details of site management and flux measurements are given by Jassal et al. [2008].

\section{Model Experiment}

\subsection{Model Initialization and Spinup}

[19] Before testing ecosys with the $\mathrm{CO}_{2}$ and $\mathrm{N}_{2} \mathrm{O}$ fluxes recorded at BC-DF49, the model had to reproduce site conditions by simulating site history. This was accomplished by initializing ecosys with the biological properties of Douglas fir and a pioneer bush understory and with the physical and chemical properties of the Quimper sandy loam (Table 1). Ecosys was also initialized with stocks of coarse and fine residue estimated to remain after a stand-replacing fire presumed to have occurred in the model year 1780. This year was selected to start the model runs so that the aboveground biomass generated by the model in 1919 was consistent with that estimated from wood volumes recorded during a 1919 timber cruise. The Douglas fir and bush were seeded after the presumed 1780 fire, grown from model 
Table 2. Changes in Stocks and Transfers of $\mathrm{C}$ and $\mathrm{N}$ Between Fertilized and Unfertilized Stands of Douglas Fir Modeled by Ecosys and Estimated From Biometric Measurements at BCDF49 on 6 December 2007 After Fertilization on 11 April 2007 $\left(\mathrm{N}_{2} \mathrm{O}\right)$ or 13 January 2007 (Others)

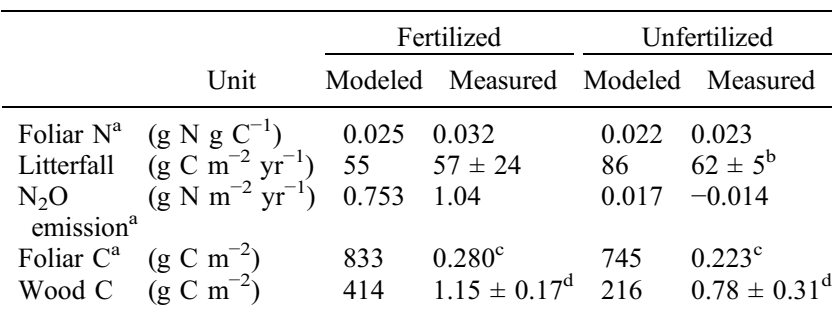

${ }^{\mathrm{a}}$ Measured data from Jassal et al. [2008].

${ }^{b}$ Litterfall in unfertilized plots from J. A. Trofymow (personal communication)

${ }^{\circ}$ Grams C per 100 needles assuming dry matter is $50 \% \mathrm{C}$.

${ }^{\mathrm{d}}$ Annual increment in bole diameter (mm) from Jassal et al. [2009].

years 1780 to 1919 under hourly weather data recorded at BC-DF49 during 2004, then from model years 1920 to 1997 under daily weather data constructed from meteorological records [Régnière and St-Amant, 2007], and then from 1998 to 2006 under hourly weather data recorded at BC-DF49 during 1998-2006. The modeled Douglas fir stand was burnt in 1939, salvage logged and burnt again in 1943, reseeded in 1949, and fertilized with $20 \mathrm{~g} \mathrm{~N} \mathrm{~m}^{-2}$ as broadcast urea in 1994 so that the age and disturbance history of the modeled stand at the end of 2006 corresponded to that at $\mathrm{BC}-\mathrm{DF} 49$ as derived from field records.

\subsection{Boundary Conditions}

[20] During the model run, atmospheric $\mathrm{CO}_{2}$ concentration $\left(C_{\mathrm{a}}\right)$ was prescribed to rise exponentially from 280 to $385 \mu \mathrm{mol} \mathrm{mol}{ }^{-1}$, and concentrations of $\mathrm{NH}_{4}^{+}$and $\mathrm{NO}_{3}^{-}$in precipitation used to simulate wet $\mathrm{N}$ deposition were prescribed to rise from historical values based on Holland et al. [1999] to current values based on Meteorological Service of Canada [2004]. Atmospheric concentration of $\mathrm{NH}_{3}$ used to simulate dry $\mathrm{N}$ deposition was maintained at $0.002 \mu \mathrm{mol}$ $\mathrm{mol}^{-1}$. A background mortality rate of $0.75 \%$ per year was applied to Douglas fir during model runs, simulating natural self-thinning.

\subsection{Model Testing}

[21] The model run was then continued during 2007 under hourly weather data recorded at BC-DF49, with and without $20 \mathrm{~g} \mathrm{~N} \mathrm{~m}^{-2}$ of urea broadcast on 13 January to simulate changes in $\mathrm{CO}_{2}$ exchange, or on 11 April to simulate changes in $\mathrm{N}_{2} \mathrm{O}$ emissions. The ability of the model to simulate changes in forest productivity with $\mathrm{N}$ fertilizer was evaluated by testing modeled $\mathrm{CO}_{2}$ fluxes against $\mathrm{EC} \mathrm{CO}_{2}$ flux measurements under comparable environmental conditions before and after fertilization. The ability of the model to simulate changes in $\mathrm{N}_{2} \mathrm{O}$ emissions with $\mathrm{N}$ fertilizer was evaluated by testing modeled $\mathrm{N}_{2} \mathrm{O}$ fluxes against surface chamber measurements recorded on the fertilized versus unfertilized plots near BC-DF49. To examine longer-term effects of the 2007 fertilization, these model runs were extended by a further 10 years until the likely harvest date of the stand, under weather recorded during 2005, a meteorologically near-average year. Values of all model parameters in this study were unchanged from those in earlier studies [e.g., Grant, 2004; Grant et al., 2005, 2006a, 2006c, 2007b, 2007c].

\section{Results}

\subsection{Uptake and Assimilation of Fertilizer $\mathbf{N}$}

[22] Fertilization on 13 January 2007 hastened root uptake and root-shoot transfer of $\mathrm{N}$ in the model, raising average needle $\mathrm{N}$ content of Douglas fir by $14 \%$ from $0.022 \mathrm{~g} \mathrm{~N} \mathrm{~g}$ $\mathrm{C}^{-1}$ in the unfertilized stand to $0.025 \mathrm{~g} \mathrm{~N} \mathrm{~g} \mathrm{C}^{-1}$ in the fertilized stand by 6 December 2007, about 11 months after fertilization (Table 2). This increase was smaller than one from 0.023 to $0.032 \mathrm{~g} \mathrm{~N} \mathrm{~g} \mathrm{C}^{-1}$ (assuming needles are $50 \% \mathrm{C}$ ) measured at BC-DF49 on this date by Jassal et al. [2008], but similar to one from 0.022 to $0.027 \mathrm{~g} \mathrm{~N} \mathrm{~g} \mathrm{C}^{-1}$ measured by Nason et al. [1990] 30 weeks after applying $20 \mathrm{~g} \mathrm{~N} \mathrm{~m}^{-2}$ as urea to a nearby Douglas fir stand of similar age.

[23] In the model, this rise was driven by hydrolysis of the urea fertilizer to $\mathrm{NH}_{3}$ (equation (A1a)) and equilibration with $\mathrm{NH}_{4}^{+}$(equation (Alb)), which drove nitrification to $\mathrm{NO}_{2}^{-}$(equation (A3a)), and $\mathrm{NO}_{3}^{-}$(equation (A3b)) [Grant, 1994], and reduction of $\mathrm{NO}_{2}^{-}$to $\mathrm{N}_{2} \mathrm{O}$ (A3d) [Grant, 1995]. The $\mathrm{NH}_{4}^{+}$and $\mathrm{NO}_{3}^{-}$products of hydrolysis and nitrification were also subject to competitive uptake by microbial populations (A2b and A2c) [Grant et al., 1993a, 1993b] and by root and mycorrhizal populations (equations (A6a)(A6d)) [Grant, 1998]. Root and mycorrhizal uptake products raised root and mycorrhizal nonstructural $\mathrm{N}$ concentrations (equation (A7c)) and thereby transfers to shoot nonstructural $\mathrm{N}$ (equations (A7a) and (A7b)), raising shoot nonstructural $\mathrm{N}$ (equation (A7d)) and hence the N/C ratio of leaf structural growth (equation (A7e)) that determined the foliar $\mathrm{N}$ concentrations.

\subsection{Fertilization and $\mathrm{Net} \mathrm{CO}_{2}$ Exchange}

[24] Greater foliar N content in the model raised photosynthetic capacity (equations (A7i) and (A7j)), rubisco activation (equation $(\mathrm{A} 7 \mathrm{k})$ ), and hence $\mathrm{CO}_{2}$ fixation rates (equations (A7f), (A7g), and (A7h)) [Grant et al., 2001] in the fertilized stand. Greater $\mathrm{CO}_{2}$ fixation rates caused more rapid $\mathrm{CO}_{2}$ influxes to be modeled and measured during 2007 than under comparable weather in 2001 (e.g., DOY $163-169$ in Figure $2 b$ versus $2 d$ ), the year meteorologically most similar to 2007 within the instrumental period prior to fertilization as apparent from meteorological data summarized in Table 3. However, $\mathrm{CO}_{2}$ effluxes modeled or gapfilled during 2007 were comparable to those during 2001, causing net $\mathrm{C}$ uptake to rise with fertilization.

[25] Rapid net $\mathrm{C}$ uptake modeled and measured in 2007 (Figure $2 \mathrm{~b}$ ) allowed daily net ecosystem productivity (NEP) to rise with air temperature $\left(T_{\mathrm{a}}\right)$ and day length to maximum values of 5-6 $\mathrm{g} \mathrm{C} \mathrm{m}^{-2} \mathrm{~d}^{-1}$ sustained during May and June (Figure 3b). Daily NEP subsequently declined with $T_{\mathrm{a}}$ and day length after the summer solstice but remained positive (C sink) until mid-October. Slower net $\mathrm{C}$ uptake modeled and measured in 2001 (Figure 2d) caused maximum daily NEP of 4-5 g C m$~^{-2} \mathrm{~d}^{-1}$ to be sustained only to mid-May, after which NEP declined to near zero (C neutral) by midSeptember, about 1 month earlier than in 2007 (Figures 3d versus $3 b$ ). Lower maxima and earlier declines in daily NEP were also modeled and measured in 2006, the year 

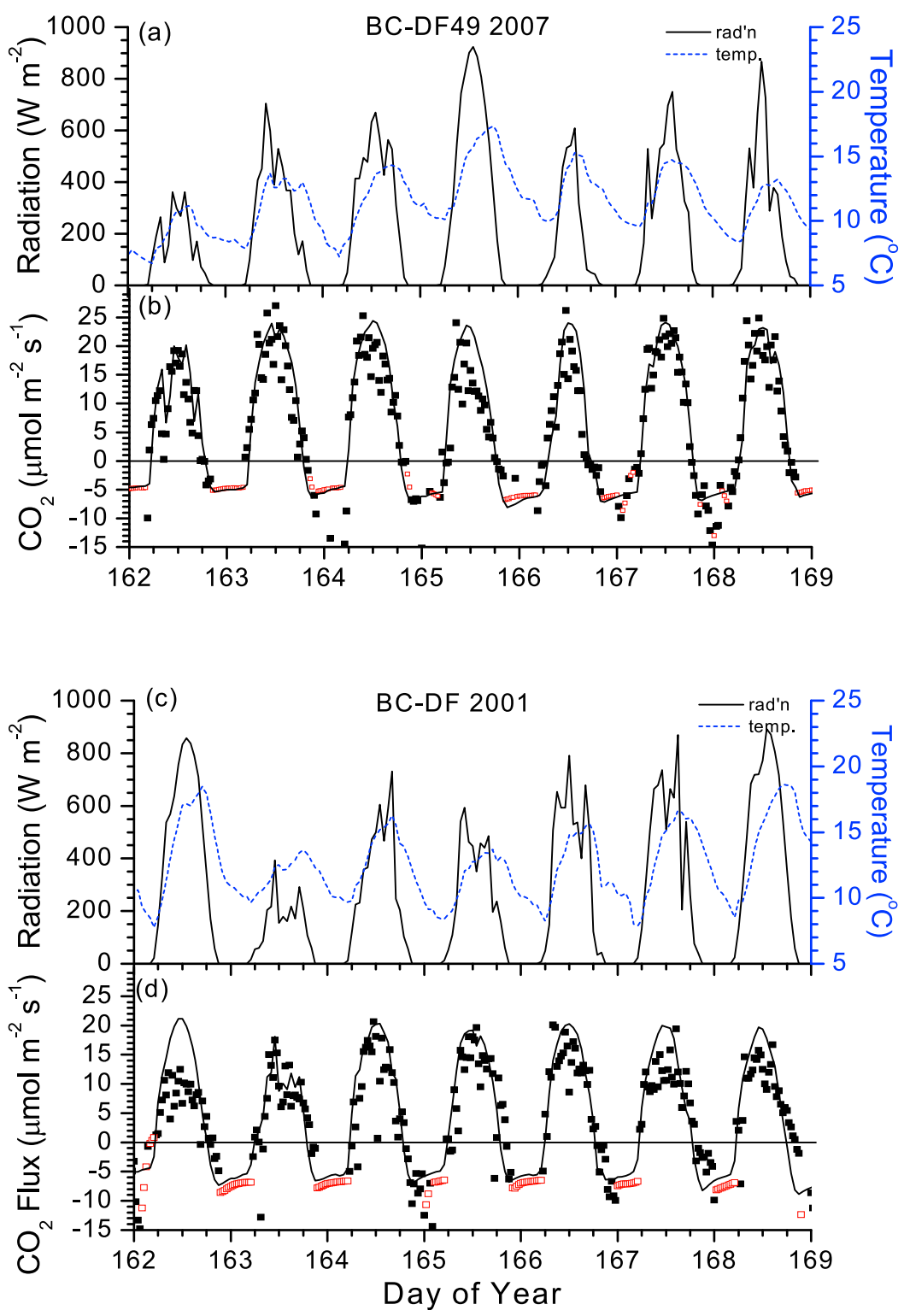

Figure 2. (a, c) Incoming shortwave radiation and air temperature and (b, d) $\mathrm{CO}_{2}$ fluxes measured (solid symbols), gap filled (open symbols), and modeled (lines) during DOY 163-169 (12-18 June) in 2007 after fertilization (Figures $2 \mathrm{a}$ and $2 \mathrm{~b}$ ) and in 2001 before fertilization (Figures $2 \mathrm{c}$ and 2d) over a Douglas fir stand fertilized on 13 January 2007. Positive fluxes represent $\mathrm{CO}_{2}$ uptake; negative fluxes represent $\mathrm{CO}_{2}$ emission.

before fertilization (Figure 4), as well as in other earlier years at this site [Grant et al., 2009], indicating a consistent seasonal pattern in NEP before fertilization.

[26] These earlier seasonal declines in NEP prior to fertilization in 2007 were modeled from earlier seasonal declines in foliar nonstructural $\mathrm{N}$ content (equation (A7d)) and hence in foliar structural $\mathrm{N}$ content (equation (A7e)) and rubisco activation (equation (A7k)) as described in section 5.1. Seasonal declines in foliar nonstructural $\mathrm{N}$ content occurred when rates of nonstructural $\mathrm{N}$ assimilation driven from biomass growth (equation (A7e)) exceeded rates of nonstructural $\mathrm{N}$ transfer (equations (A7a) and (A7b)) from roots driven from mineral $\mathrm{N}$ uptake by roots and mycorrhizae (equations (A6a)-(A6d)). These modeled declines were delayed in 2007 by additional mineral $\mathrm{N}$ uptake of fertilizer products. Net $\mathrm{C}$ uptake in all 3 years was adversely affected by several brief warming events (Figures 3a and $3 \mathrm{c}$ ), as measured and modeled in other years at this site [Grant et al., 2007c, 2009].

[27] To test consistency of model performance before and after fertilization, hourly modeled $\mathrm{CO}_{2}$ fluxes were regressed on hourly averaged $\mathrm{EC} \mathrm{CO}_{2}$ fluxes measured under conditions of adequate turbulence during each year from 1998 to 2007 (i.e., excluding gap-filled values). Parameters and correlation coefficients from this regression in 2007 were very similar to those from 1998 to 2006 before fertilizer application $\left(b=1.0, R^{2}=0.8, \mathrm{RMSD}=3.4 \mu \mathrm{mol} \mathrm{m}^{-2}\right.$ $\mathrm{s}^{-1}$ in Table 3), indicating that the model response to added $\mathrm{N}$ did not introduce a bias into modeled $\mathrm{CO}_{2}$ fluxes with respect to measured values. 
Table 3. Mean Annual Temperatures, Annual Precipitation, Intercepts, Slopes, Coefficients of Determination, Root Mean Square of Differences, and Number of Accepted Eddy Covariance fluxes From Regressions of Hourly Modeled $\mathrm{CO}_{2}$ Fluxes Versus Hourly Averaged EC $\mathrm{CO}_{2}$ Fluxes Measured at BC-DF49 From 1998 to $2007^{\mathrm{a}}$

\begin{tabular}{|c|c|c|c|c|c|c|c|}
\hline Year & MAT $\left({ }^{\circ} \mathrm{C}\right)$ & Precip (mm) & $a\left(\mu \mathrm{mol} \mathrm{m}{ }^{-2} \mathrm{~s}^{-1}\right)$ & $b$ & $R^{2}$ & $\begin{array}{c}\text { RSMD } \\
\left(\mu \mathrm{mol} \mathrm{m}^{-2} \mathrm{~s}^{-1}\right)\end{array}$ & $n$ \\
\hline 1998 & 9.10 & 1844 & 0.24 & 1.10 & 0.75 & 3.3 & 5187 \\
\hline 1999 & 7.64 & 1913 & 0.40 & 1.09 & 0.77 & 3.1 & 4982 \\
\hline 2000 & 8.21 & 1127 & 0.43 & 1.02 & 0.76 & 3.5 & 4954 \\
\hline 2001 & 8.09 & 1166 & 0.36 & 1.01 & 0.77 & 3.3 & 4990 \\
\hline 2002 & 8.48 & 1222 & 0.54 & 1.07 & 0.75 & 3.4 & 5026 \\
\hline 2003 & 8.48 & 1621 & 0.33 & 1.04 & 0.77 & 3.4 & 5277 \\
\hline 2004 & 8.77 & 1404 & 0.63 & 0.99 & 0.75 & 3.8 & 4362 \\
\hline 2005 & 8.31 & 1467 & 0.91 & 0.96 & 0.77 & 3.8 & 4388 \\
\hline 2006 & 8.40 & 1809 & 0.13 & 1.02 & 0.76 & 3.4 & 5233 \\
\hline $2007^{\mathrm{b}}$ & 7.71 & 1482 & 0.40 & 1.04 & 0.80 & 3.4 & 5235 \\
\hline
\end{tabular}

${ }^{\mathrm{a}}$ MAT, mean annual temperatures; Precip, annual precipitation; $a$, intercepts; $b$, slopes; $R^{2}$, coefficients of determination; RMSD, root mean square of differences; EC, number of accepted eddy covariance fluxes.

${ }^{\mathrm{b}} \mathrm{Urea}$ applied at $20 \mathrm{~g} \mathrm{~N} \mathrm{~m}^{-2}$ on 13 January 2007.

\subsection{Fertilization and Net Primary Productivity}

[28] Greater $\mathrm{CO}_{2}$ fixation rates modeled during 2007 with $\mathrm{N}$ fertilization (Figures 2 and 3 ) caused a $14 \%$ gain in annual gross primary productivity (GPP) from that modeled in 2007 without fertilization, consistent with a $10 \%$ gain estimated from EC measurements by Jassal et al. [2009] (Table 4). However, fertilizer $\mathrm{N}$ had very different effects on $R_{\mathrm{a}}$ and net primary productivity (NPP) of shoots versus roots. Shoot $R_{\mathrm{a}}$ modeled during 2007 rose $21 \%$ with fertilization, driven by greater $R_{\mathrm{g}}$ and $R_{\mathrm{m}}$ required for greater biomass growth and maintenance [Grant et al., 2007c, equations (C12)-(C16)]. Root $R_{\mathrm{a}}$ modeled during 2007 also rose slightly with fertilization during the first 3 months after application but decreased thereafter so that cumulative root $R_{\mathrm{a}}$ at the end of the year was slightly lower. Shoot NPP in the model rose $43 \%$ with fertilization by the end of 2007 , while root NPP declined by $33 \%$ (Table 4 ).

[29] In the model, these differences in shoot versus root responses to fertilization arose from reduced below-ground allocation of the nonstructural C product of GPP caused by more rapid consumption of nonstructural $\mathrm{C}$ in shoot growth and $R_{\mathrm{a}}$ (equations $(\mathrm{A} 7 \mathrm{~d})$ and $(\mathrm{A} 7 \mathrm{e})$ ) with more rapid $\mathrm{N}$ uptake from fertilization. This consumption lowered concentration gradients of nonstructural $\mathrm{C}$ that drove transfer to roots (equation (A7a)), thereby implementing the functional equilibrium by which shoot and root growth are thought to be governed.

\subsection{Fertilization and Heterotrophic Respiration}

[30] Fertilization lowered heterotrophic respiration $\left(R_{\mathrm{h}}\right)$ by $6 \%$ from that modeled without fertilization during 2007 (Table 4). This reduction arose from reduced shoot-root $\mathrm{C}$ transfer with fertilization which caused lower nonstructural $\mathrm{C}$ concentrations in roots and mycorrhizae and hence less exudation of nonstructural C to soil [Grant, 1993]. Furthermore, by raising GPP in the model, fertilization raised production of nonstructural $\mathrm{C}$, thereby reducing remobilization of foliar and root structural $\mathrm{C}$ needed to meet $R_{\mathrm{m}}$ requirements and hence reducing shoot and root litterfall driven by remobilization [Grant et al., 2007c, equations (C14)-(C18)]. However, measurements in the fertilized versus unfertilized field plots at BC-DF49 indicated no significant reduction in foliar litterfall with fertilization (Table 2). Less litterfall and exudates modeled with fertilization in 2007 provided less substrate for decomposition [Grant et al., 2007c, equation (A3)] and hence for $R_{\mathrm{h}}$ and microbial growth [Grant et al., 2007c, equations (A13) and (A28)].

[31] Lower $R_{\mathrm{h}}$ partially offset higher root $R_{\mathrm{a}}$ modeled during the first three months after fertilizer application, so that soil respiration $\left(R_{\mathrm{s}}=R_{\mathrm{h}}+\right.$ below-ground $\left.R_{\mathrm{a}}\right)$ rose only slightly during this period. Thereafter lower $R_{\mathrm{h}}$ and lower root $R_{\mathrm{a}}$ reduced $R_{\mathrm{S}}$ so that cumulative $R_{\mathrm{S}}$ modeled at the end of 2007 was about $5 \%$ lower with fertilization (Table 4). Greater $R_{\mathrm{S}}$ was also measured with surface flux chambers during the first 3-4 months after application in the fertilized versus unfertilized field plots near the BC-DF49 flux tower, while similar $R_{\mathrm{S}}$ was measured in both treatments thereafter, so that cumulative $R_{\mathrm{s}}$ measured at the end of 2007 was estimated to have been raised by about $6 \%$ with fertilization [Jassal et al., 2010] (Table 4). Both modeled and measured results thus indicated only small changes in $R_{\mathrm{S}}$ with fertilization.

\subsection{Fertilization, Net Ecosystem Productivity, and Growth}

[32] Greater gains in GPP versus ecosystem respiration $\left(R_{\mathrm{e}}=R_{\mathrm{a}}+R_{\mathrm{h}}\right)$ caused a $39 \%$ gain in net ecosystem productivity (NEP) to be modeled with fertilization, similar to a $37 \%$ gain estimated from EC measurements by Jassal et al. [2009] (Table 4). Somewhat larger modeled versus measured NEP may partly be attributed to subsurface leaching of dissolved inorganic C (DIC), which was assumed in the model to have been lost from the site, but some of which may in fact have volatilized within the fetch area and so have been detected at the EC tower.

[33] By the end of 2007, fertilization caused a substantial rise in shoot $\mathrm{C}$ and a decline in $\operatorname{root} \mathrm{C}$ in the model (Table 4), driven by a rise in shoot NPP, a decline in root NPP and declines in both shoot and root litterfall. However, fertilization reduced gains in soil organic $\mathrm{C}$ (SOC) during the first year after application because it reduced litterfall more than it $\operatorname{did} R_{\mathrm{s}}$. 

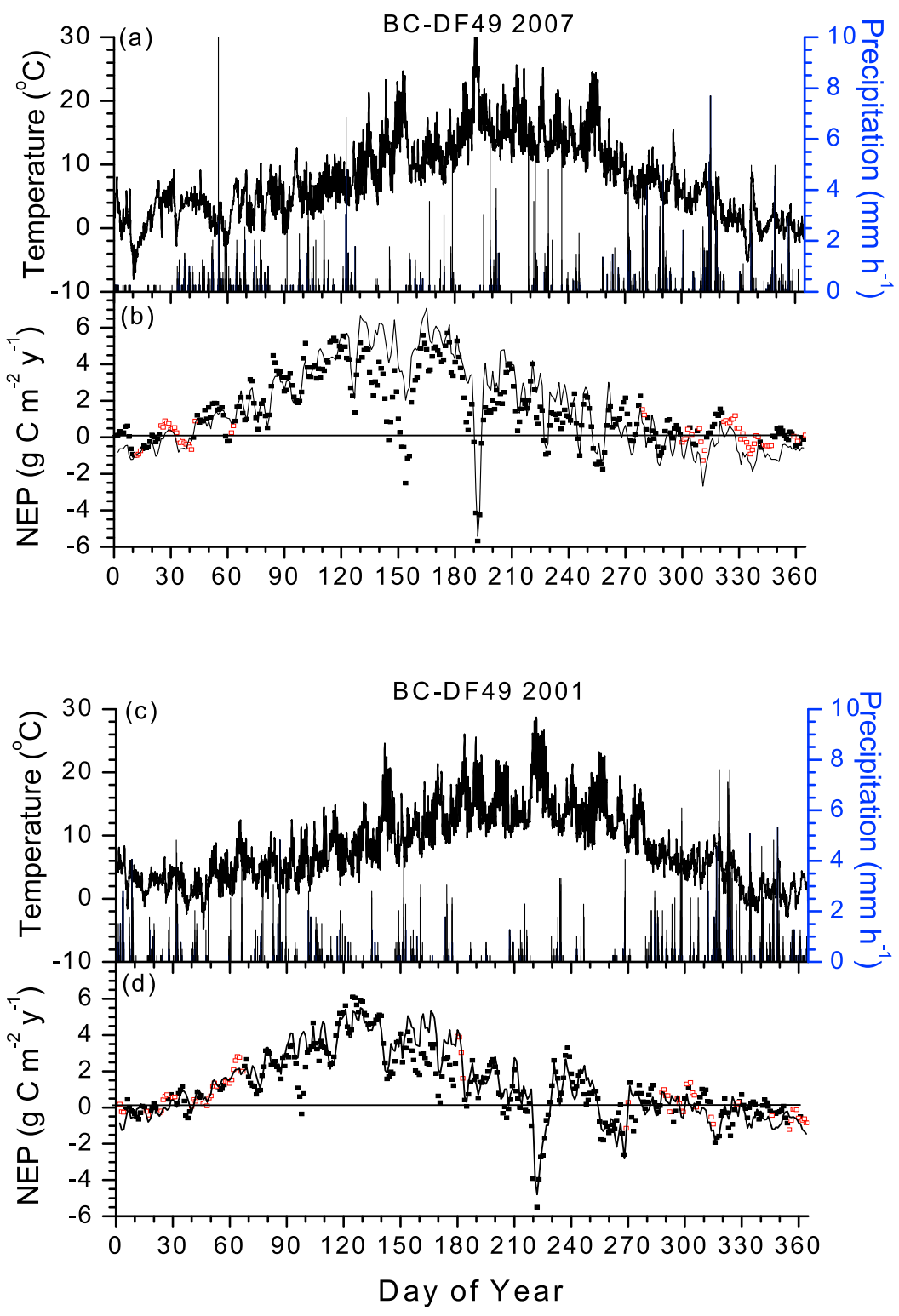

Figure 3. (a, c) Air temperature (line), precipitation (bars), and (b, d) daily net ecosystem productivity (NEP) calculated from gap-filled EC measurements (symbols) or modeled (line) during 2007 after fertilization (Figures 3a and 3b) and during 2001 before fertilization (Figures 3c and 3d) over a Douglas fir stand fertilized on 13 January 2007. Positive NEP represents net $\mathrm{CO}_{2}$ uptake; negative NEP represents net $\mathrm{CO}_{2}$ emission. Solid or open symbols represent daily $\mathrm{EC}$ values derived from gap-filling less or more than 24 half-hourly values, respectively.

\subsection{Fertilization and $\mathrm{N}_{2} \mathrm{O}$ Emissions}

[34] Emissions of $\mathrm{N}_{2} \mathrm{O}$ modeled in the fertilized stand and measured in the fertilized field plots were temporally variable but continuous during most of 2007, while emissions modeled in the unfertilized stand and measured in the unfertilized field plots were negligible (Figure 5). Total emissions of $\mathrm{N}_{2} \mathrm{O}$ attributed to the fertilizer from application on 11 April 2007 to the end of the year were $0.74 \mathrm{~g} \mathrm{~N} \mathrm{~m}^{-2}$ from differences between fertilized and unfertilized stands in the model and $1.05 \mathrm{~g} \mathrm{~N} \mathrm{~m}^{-2}$ derived from differences in measurements of surface fluxes and subsurface concentration gradients in the fertilized versus unfertilized field plots by Jassal et al. [2008] (Table 2). These emissions accounted for $3.7 \%$ and $5.2 \%$ of the added fertilizer $\mathrm{N}$ in the model and the field plots, respectively.

[35] In the model, emissions were driven by urea hydrolysis (equations (A1a) and (A1b)) which accelerated $\mathrm{NH}_{4}^{+}$ oxidation to $\mathrm{NO}_{2}^{-}$(equation (A3a)) and $\mathrm{NO}_{3}^{-}$(equation (A3b)) [Grant, 1994], and hence $\mathrm{NO}_{3}^{-}$reduction to $\mathrm{NO}_{2}^{-}$ (equation (A4a)) and $\mathrm{NO}_{2}^{-}$reduction to $\mathrm{N}_{2} \mathrm{O}$ (equations (A3d) and (A4b)) [Grant, 1995; Grant et al., 2006b]. These reductions were driven by demand from oxidation reactions for electron acceptors unmet by $\mathrm{O}_{2}$. However, this demand was strongly limited by aerated conditions in the surface residue to which the urea was added. Rises in $\mathrm{NO}_{2}^{-}$ concentrations from accelerated $\mathrm{NH}_{4}^{+}$oxidation caused rises 


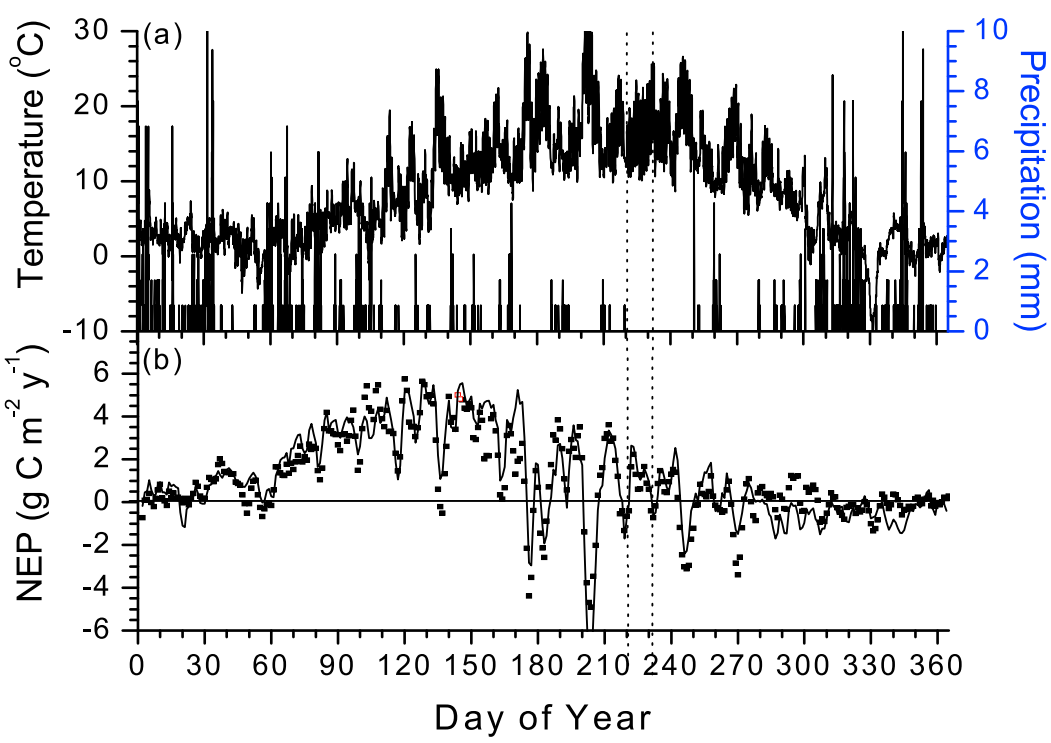

Figure 4. (a) Air temperature (lines), precipitation (bars), and (b) daily net ecosystem productivity (NEP) calculated from gap-filled EC measurements (symbols) or modeled (line) during 2006 before fertilization over a Douglas fir stand fertilized on 13 January 2007. Positive NEP represents net $\mathrm{CO}_{2}$ uptake; negative NEP represents net $\mathrm{CO}_{2}$ emission. Solid or open symbols represent daily EC values derived from gap-filling less or more than 24 half-hourly values, respectively.

in $\mathrm{HNO}_{2}$ in the model (equation (A5a)) under the low $\mathrm{pH}$ of Douglas fir residue ( 4.75 in the work of Welke and Hope [2005]). $\mathrm{HNO}_{2}$ drove $\mathrm{NO}_{2}^{-}$reduction through chemodenitrification (equation (A5b)), a fraction of which generated $\mathrm{N}_{2} \mathrm{O}$ (equation (A5c)). Large $\mathrm{HNO}_{2}$ concentrations also slowed $\mathrm{NO}_{2}^{-}$oxidation (equation (A3c)), sustaining the $\mathrm{HNO}_{2}$ concentrations driving chemodenitrification.

\subsection{Fertilization and Changes in Ecosystem $C$}

[36] Increased GPP from fertilization caused aggregated gap-filled EC fluxes to rise by about $150 \mathrm{~g} \mathrm{C} \mathrm{m}^{-2} \mathrm{yr}^{-1}$ during the first year after application, similar to the modeled rise (Figure 6a). In the model, NEP of the fertilized stand was predicted to decline after 2007, rapidly for the first few years and then more slowly thereafter. NEP of the unfertilized stand was also predicted to decline with forest age [Grant et al., 2007c] but more slowly than that of the fertilized stand, so that the two values of NEP gradually converged. The larger modeled versus EC-derived values may be partly attributed to the accounting of DIC losses as described earlier (Table 4).

[37] The modeled gains in NEP from fertilization were found mostly in wood $\mathrm{C}$ and partly in foliage $\mathrm{C}$ (Figure $6 \mathrm{~b}$ ). By 6 December 2007, about 11 months after fertilization, foliar $\mathrm{C}$ in the model rose $12 \%$ from $745 \mathrm{~g} \mathrm{C} \mathrm{m}^{-2}$ in the unfertilized stand to $833 \mathrm{~g} \mathrm{C} \mathrm{m}^{-2}$ in the fertilized stand, comparable to a rise in 100-needle $\mathrm{C}$ of $23 \%$ from 0.223 to $0.280 \mathrm{~g}$ measured on this date in the unfertilized versus fertilized field plots by Jassal et al. [2008] (Table 2). By this same date wood $\mathrm{C}$ growth in the model rose $92 \%$ from 216 to $414 \mathrm{~g} \mathrm{C} \mathrm{m}^{-2} \mathrm{yr}^{-1}$, which was greater than a rise of $47 \%$ in tree ring growth measured in the fertilized versus unfertilized plots in 2007 (Table 2). Gains in wood C growth declined during the years after fertilization, so that cumulative gains in wood $\mathrm{C}$ rose more slowly with time, while gains in foliage $\mathrm{C}$ were reversed after several years and eventually lost (Figure 6b).

[38] Changes in tree $\mathrm{C}$ allocation and hence in shoot versus root NPP with fertilization caused modeled gains in wood and foliage $\mathrm{C}$ to be partly offset by losses in soil, root and nonstructural $\mathrm{C}$ during the first 3-5 years after fertilization (Figure 6c). These losses were caused by more rapid use of nonstructural $\mathrm{C}$ in foliage and wood growth (equations (A7d) and (A7e)) which reduced transfers of nonstructural $\mathrm{C}$ to roots and mycorrhizae (equation (A7a)) as described earlier. Declines in soil $\mathrm{C}$ modeled more than 2 years after fertilization were partly offset by rises in surface litter C (Figure 6c) caused by more rapid aboveground litterfall from larger foliar and wood phytomass. Declines in below-ground $\mathrm{C}$ were eventually reversed, so that soil, root, foliage and nonstructural $\mathrm{C}$ gradually returned to values similar to those modeled in the unfertilized stand by 11 years after fertilization.

\subsection{Fertilization and Changes in Ecosystem $\mathbf{N}$}

[39] Changes in ecosystem $\mathrm{C}$ stocks modeled after fertilization were associated with those in ecosystem $\mathrm{N}$ stocks. At the end of 2007, the added fertilizer $\mathrm{N}$ in the model was found mostly in nonstructural and foliage $\mathrm{N}$ through root uptake (equations (A6a)-(A6d)) and root-shoot transfer (equation (A7b)) (Figure 6d). These gains were partly offset by a decline in root $\mathrm{N}$ (Figure 6e) associated with that in root $\mathrm{C}$ (Figure 6c). Some of the added fertilizer was retained in soil and surface litter (Figure 6e) through litterfall [Grant et al., 2007c, equation (C18)], mineralization (equation (A2a)), and immobilization (equations (A2b) and (A2c)), or lost to groundwater mostly as $\mathrm{NO}_{3}^{-}$through nitrification (equations (A3a) and (A3b)) and leaching (Figure 6e), or emitted to the atmosphere as $\mathrm{N}_{2} \mathrm{O}$ and $\mathrm{N}_{2}$ (Figure 6e) from nitrification (equation (A3d)), denitrification (equation (A4b)), and 
Table 4. Annual Carbon Fluxes and Changes in Key C Stocks From Fertilized and Unfertilized Stands of Douglas Fir Modeled By Ecosys and Estimated From Eddy Covariance Measurements at BC-DF49 in 2007

\begin{tabular}{|c|c|c|c|c|}
\hline & \multicolumn{2}{|c|}{ Fertilized } & \multicolumn{2}{|c|}{ Unfertilized } \\
\hline & Modeled & Measured & Modeled & Measured \\
\hline \multicolumn{5}{|c|}{ Fluxes $^{\mathrm{a}}\left(\mathrm{gCm^{-2 }} y \mathrm{r}^{-1}\right)$} \\
\hline GPP & 2459 & 1944 & 2161 & $1760^{\mathrm{b}}$ \\
\hline \multicolumn{5}{|l|}{$R_{\mathrm{a}}$} \\
\hline Shoot & 1012 & & 838 & \\
\hline $\operatorname{Root}^{\mathrm{c}}$ & 439 & & 455 & \\
\hline Total & 1451 & & 1293 & \\
\hline \multicolumn{5}{|l|}{$N P P$} \\
\hline Shoot & 801 & & 560 & \\
\hline $\operatorname{Root}^{\mathrm{c}}$ & 207 & & 308 & \\
\hline Total & 1008 & & 868 & \\
\hline \multicolumn{5}{|l|}{ Litter } \\
\hline Foliage & 55 & & 86 & \\
\hline Other $A G^{\mathrm{d}}$ & 211 & & 190 & \\
\hline $\operatorname{Root}^{\mathrm{c}, \mathrm{e}}$ & 264 & & 318 & \\
\hline Total & 530 & & 594 & \\
\hline$R_{\mathrm{h}}$ & 417 & & 443 & \\
\hline$R_{\mathrm{S}}$ & 856 & 921 & 897 & $862^{\mathrm{b}}$ \\
\hline$R_{e}$ & 1868 & 1397 & 1736 & $1362^{\mathrm{b}}$ \\
\hline NEP (atm) & 591 & 547 & 425 & $398^{\mathrm{b}}$ \\
\hline DIC, DOC ${ }^{\mathrm{f}}$ & 53 & & 57 & \\
\hline \multicolumn{5}{|c|}{ Stock Changes $\left(\mathrm{g} \mathrm{C}^{-2}\right)$} \\
\hline$\triangle \mathrm{ABC}^{\mathrm{c}}$ & & & & \\
\hline Living & 476 & & 225 & \\
\hline Dead & 59 & & 59 & \\
\hline \multicolumn{5}{|l|}{$\Delta \mathrm{BGC}^{\mathrm{h}}$} \\
\hline $\operatorname{Root}^{\mathrm{a}}$ & -83 & & -7 & \\
\hline Storage & 25 & & -1 & \\
\hline$\triangle \mathrm{SOC}$ & 58 & & 89 & \\
\hline$\Delta$ Soil $\mathrm{CO}_{2}$ & 3 & & 3 & \\
\hline Total & 538 & & 368 & \\
\hline
\end{tabular}

${ }^{\mathrm{a}}$ Abbreviations: $R_{\mathrm{a}}$, autotrophic respiration; $R_{\mathrm{h}}$, heterotrophic respiration; $R_{\mathrm{s}}$, ecosystem respiration; DIC, dissolved inorganic carbon; DOC, dissolved organic carbon; $\mathrm{ABC}$, aboveground plant carbon; BGC, belowground plant carbon; SOC, soil organic carbon.

${ }^{\mathrm{b}}$ From an empirical model fitting measured $\mathrm{C}$ fluxes to climate variables from 1998 to 2006 and used to estimate C fluxes from climate variables in 2007 by Jassal et al. [2009, 2010].

${ }^{\mathrm{c}}$ All root terms include mycorrhizae.

${ }^{\mathrm{d}}$ Includes twig, reproductive material, coarse woody litter.

encludes litterfall plus exudation.

${ }^{\mathrm{f}}$ Dissolved inorganic and organic $\mathrm{C}$ (mostly aqueous $\mathrm{CO}_{2}$, carbonates) exported in runoff and drainage water.

${ }^{g}$ Aboveground $\mathrm{C}$, including foliage, twigs, boles, reproductive material, and nonstructural $\mathrm{C}$

${ }^{\mathrm{h}} \mathrm{Below}$-ground $\mathrm{C}$, including coarse and fine roots, mycorrhizae, and nonstructural $\mathrm{C}$.

chemodenitrification (equation (A5c)) (Figure 5). After 2007, there was a gradual translocation of added $\mathrm{N}$ out of nonstructural stocks into foliage stocks and after 2010 out of nonstructural and foliage stocks into soil, wood, and root stocks (Figure 6d versus 6e). Losses of added $\mathrm{N}$ through leaching and gaseous emissions in the model were negligible after 2007 (Figure 6e), as was found from measurements of emissions at BC-DF49 in 2008 [Jassal et al., 2010].

\section{Discussion}

\subsection{Fertilizer $\mathbf{N}$ and Aboveground Productivity}

[40] Productivity at the BC-DF49 site was likely limited by $\mathrm{N}$, as evidenced by foliar $\mathrm{N}$ concentrations of only

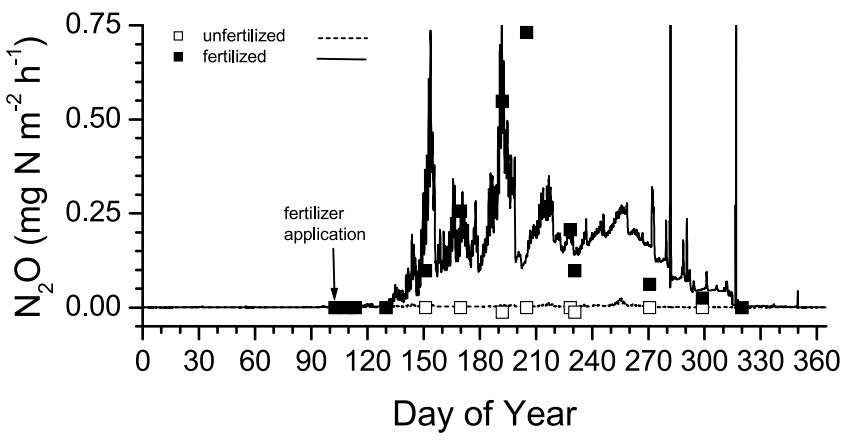

Figure 5. $\mathrm{N}_{2} \mathrm{O}$ emissions measured (symbols) and modeled (lines) during 2007 from Douglas fir stands that were not fertilized or fertilized with $20 \mathrm{~g} \mathrm{~N} \mathrm{~m}^{-2}$ as urea on 11 April 2007 (DOY 101).

$0.022 \mathrm{~g} \mathrm{~N} \mathrm{~g} \mathrm{C}^{-1}$ modeled in the unfertilized stand and $0.023 \mathrm{~g} \mathrm{~N} \mathrm{~g} \mathrm{C}^{-1}$ measured in the unfertilized field plots (Table 2). These concentrations were much lower than 0.029 $\mathrm{g} \mathrm{N} \mathrm{g} \mathrm{C}^{-1}$ below which growth responses to $\mathrm{N}$ fertilization in Douglas fir were found by Hopmans and Chappell [1994]. The $\mathrm{N}$ concentration of the soil LFH layer at BC-DF49

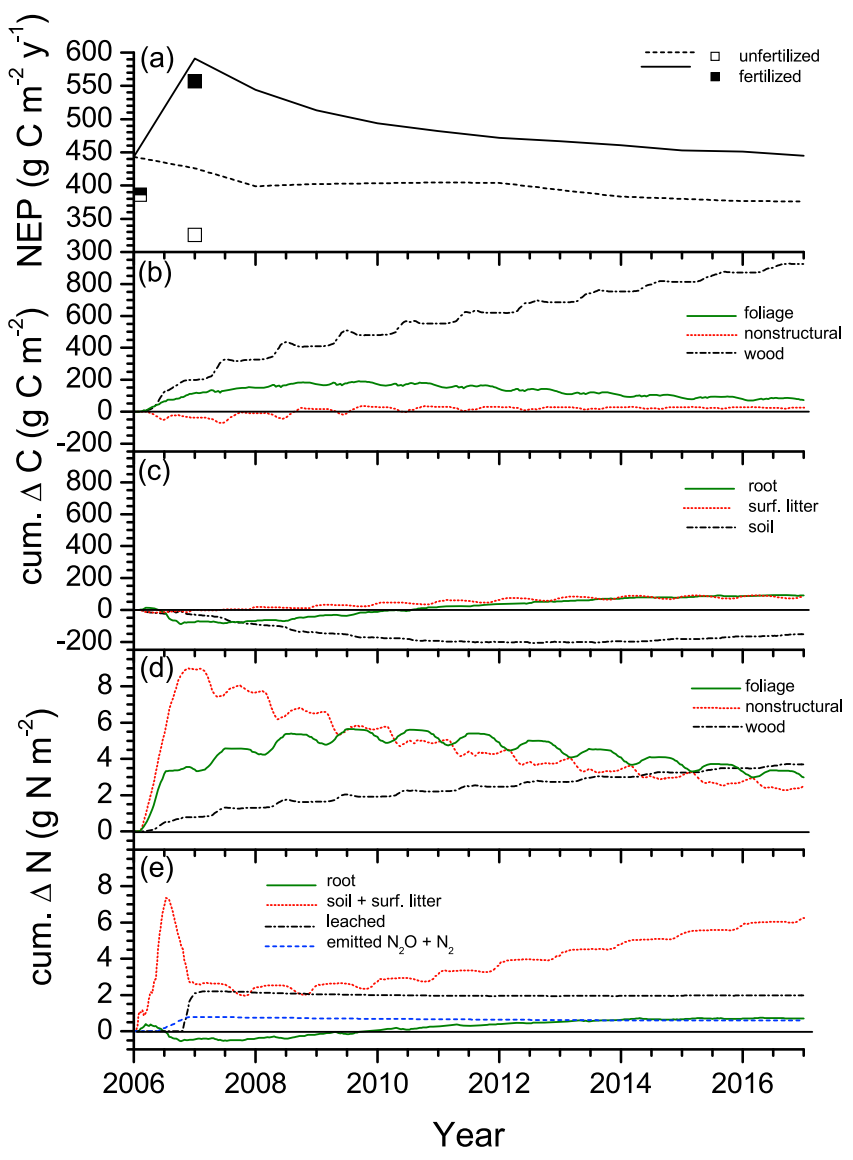

Figure 6. (a) Net ecosystem productivity (NEP) and cumulative changes in (b) aboveground and (c) below-ground $\mathrm{C}$ stocks, and (d) aboveground and (e) below-ground N stocks and fluxes modeled (lines) and measured (symbols in Figure $6 a)$ over 11 years in a Douglas fir stand fertilized on 11 January 2007 versus an unfertilized Douglas fir stand. 
(0.021 $\mathrm{g} \mathrm{N} \mathrm{g} \mathrm{C}^{-1}$ from Table 1$)$ was also much lower than one of $0.036 \mathrm{~g} \mathrm{~N} \mathrm{~g} \mathrm{C}^{-1}$ below which growth of Douglas fir was found by Edmonds and Hsiang [1987] to become N limited. These foliar and soil $\mathrm{N}$ contents indicated that a strong response of $\mathrm{CO}_{2}$ uptake to $\mathrm{N}$ fertilizer should be expected at BC-DF49, as modeled and measured in Figures 2 and 3.

[41] The modeled response of $\mathrm{CO}_{2}$ uptake to $\mathrm{N}$ fertilizer generated a gain in modeled wood $\mathrm{C}$ of $752 \mathrm{~g} \mathrm{C} \mathrm{m}^{-2}$ by 8 years after the $20 \mathrm{~g} \mathrm{~N} \mathrm{~m}^{-2}$ urea application (Figure 6b), which was consistent with gains measured under similar soil and climates in earlier field studies. This gain was larger than an average gain of $\sim 550 \mathrm{~g} \mathrm{C} \mathrm{m}^{-2}$ calculated from volume growth measured in field studies 8 years after applying $22.4 \mathrm{~g} \mathrm{~N} \mathrm{~m}^{-2}$ urea to young ( $<30$ years) Douglas fir stands in the nearby states of Oregon and Washington [Hopmans and Chappell, 1994; Stegemoeller and Chappell, 1990]. However, most of the stands in these studies had foliar $\mathrm{N}$ contents before fertilization that were larger than that at BC-DF49, so that a smaller response of growth to fertilizer might be expected. The time course of the modeled gain in wood $\mathrm{C}$ attributed to the fertilizer application in this study was similar to, or smaller than, ones averaging $2430 \mathrm{~g} \mathrm{C} \mathrm{m}^{-2}$ over 16 years measured by Adams et al. [2005] after four applications of $22.4 \mathrm{~g} \mathrm{~N} \mathrm{~m}^{-2}$ on soils in Washington State similar to that at BC-DF49.

\subsection{Fertilizer $\mathbf{N}$ and Below-Ground Productivity}

[42] Gains in foliar and wood $\mathrm{C}$ with fertilization in the model were partly offset for several years by declines in root and soil $\mathrm{C}$ (Table 4) which were in turn only partly offset by a rise in surface litter $\mathrm{C}$ (Figure 6c). These declines were caused by reductions in below-ground $\mathrm{C}$ allocation and hence in NPP and litterfall of roots and mycorrhizae as described earlier, so that fertilization caused net reductions in modeled root and microbial growth and hence in $R_{\mathrm{a}}, R_{\mathrm{h}}$, and $R_{\mathrm{s}}$ (Table 4). At this stage of model development, direct adverse effects of high soil $\mathrm{N}$ on $R_{\mathrm{h}}$ are not simulated because underlying mechanisms are not well understood [Berg and McClaugherty, 2003]. Therefore reductions in $R_{\mathrm{h}}$ with fertilization may have been underestimated when modeled only from reduced root $\mathrm{C}$ inputs.

[43] Reductions in $R_{\mathrm{S}}$ with fertilization in the model $(5 \%$ in Table 4) were consistent with, but usually smaller than, reductions of $R_{\mathrm{S}}$ measured after fertilization of tropical $(18 \%$ in the work of Giardina et al. [2004]), temperate (17\% in the work of Burton et al. [2004]; $25 \%$ in the work of Haynes and Gower [1995]), and boreal (40\% in the work of Olsson et al. [2005]) forests. In some studies, $R_{\mathrm{s}}$ has been found to rise slightly with fertilization for a brief period after application and to decline thereafter [Burton et al., 2004], as was modeled in this study. As in this modeling study, declines in $R_{\mathrm{s}}$ measured in these experiments were attributed to reductions in below-ground $\mathrm{C}$ allocation and hence in root and mycorrhizal growth and litterfall [Haynes and Gower, 1995] and in microbial growth [Burton et al., 2004], which were only partly offset by increases in aboveground litterfall [Giardina et al., 2004]. Some studies have indicated gains in soil $\mathrm{C}$ following fertilization, although with limited certainty [e.g., Adams et al., 2005]. These results indicate that gains in $\mathrm{C}$ sequestration attributed to fertilization must be estimated from total changes in aboveground, surface, and below-ground $\mathrm{C}$ stocks, rather than from changes in wood $\mathrm{C}$ alone.

\subsection{Retention of Fertilizer $\mathbf{N}$}

[44] The rapid early gain in NEP from fertilizer $\mathrm{N}$ in the model (Figure 6a) was driven by rapid uptake of fertilizer N, much of which appeared as nonstructural and foliar $\mathrm{N}$ in trees within the first year after application (Figure 6d). This model result is consistent with those from many field studies showing that fertilizer $\mathrm{N}$ in forests is largely taken up during the first growing season after application [Mead et al., 2008]. Six months after application, the fertilized stand in the model gained $9.5 \mathrm{~g} \mathrm{~N} \mathrm{~m}^{-2}$ in aboveground phytomass (foliage, wood, and nonstructural) and $7.4 \mathrm{~g} \mathrm{~N} \mathrm{~m}^{-2}$ in soil (mostly as nitrate) above values in the unfertilized stand (Figures $6 \mathrm{~d}$ and $6 \mathrm{e}$ ). These gains in the model were slightly larger than ones of 5.8 and $6.0 \mathrm{~g} \mathrm{~N} \mathrm{~m}^{-2}$ in trees and soil, respectively, measured by Flint et al. [2008] 6 months after a spring application of $22.4 \mathrm{~g} \mathrm{~N} \mathrm{~m}^{-2}$ as urea on a similar Douglas fir stand in nearby Washington State. However, the gains measured in their study may have been underestimated because the gain in tree $\mathrm{N}$ did not account for gain in tree biomass and the gain in soil $\mathrm{N}$ was measured only to $0.4 \mathrm{~m}$ depth and excluded the coarse organic fraction. These early gains in $\mathrm{N}$ measured in a field study conducted under conditions comparable to those at BC-DF49 corroborate the rapid uptake of fertilizer $\mathrm{N}$ in the model. The large nitrate accumulation modeled during 2007 (Figure 6e) arose from rapid nitrification of the added fertilizer, consistent with rapid nitrification measured in fertilized Douglas fir soils [Matson et al., 1992].

[45] After several years, $N$ gains modeled in the fertilized trees were distributed away from nonstructural and foliar stocks into root, wood, and soil stocks (Figures 6d and 6e). The time course of the initial rise and subsequent decline of modeled gains in foliar $\mathrm{N}$ was consistent with that of foliar fertilizer-derived $\mathrm{N}$ measured in field experiments with Douglas fir [e.g., Mead et al., 2008]. After 10 years, fertilized trees in the model gained 3.2 and $6.3 \mathrm{~g} \mathrm{~N} \mathrm{~m}^{-2}$ in foliar and nonfoliar (wood, nonstructural) phytomass, and the fertilized soil gained $6.0 \mathrm{~g} \mathrm{~N} \mathrm{~m}^{-2}$ as organic matter, above values in the unfertilized stand. These gains in the model were comparable to ones of 3.8 and $7.0 \mathrm{~g} \mathrm{~N} \mathrm{~m}^{-2}$ in foliar and nonfoliar (wood) phytomass and $8.0 \mathrm{~g} \mathrm{~N} \mathrm{~m}^{-2}$ in soil measured by Mead et al. [2008] 10 tears after applying $20 \mathrm{~g} \mathrm{~N} \mathrm{~m}^{-2}$ as urea to nearby Douglas fir stands of a similar age to that at BD-DF49. The long-term gain in soil + litter $\mathrm{N}$ with respect to soil + litter $\mathrm{C}$ in the model (Figures 6e versus 6c) caused gradual declines in soil + litter $\mathrm{C} / \mathrm{N}$ ratios following fertilization as has been measured in Douglas fir stands by Prietzel et al. [2004]. These declines indicated long-term retention of fertilizer $\mathrm{N}$ in soils with large initial $\mathrm{C} / \mathrm{N}$ ratios, enabling long-term increases in net $\mathrm{N}$ mineralization [Prietzel et al., 2004] that sustained long-term gains in ecosystem productivity (Figures 6a and 6b) [Adams et al., 2005].

\subsection{Losses of Fertilizer $\mathbf{N}$}

[46] Some of the fertilizer $N$ was not retained by the forest stand, but was lost from leaching and gaseous emissions. Of the $20 \mathrm{~g} \mathrm{~N} \mathrm{~m}^{-2}$ fertilizer $\mathrm{N}$ added in the model on 13 January, $2.1 \mathrm{~g} \mathrm{~N} \mathrm{~m}^{-2}$ was leached and $0.8 \mathrm{~g} \mathrm{~N} \mathrm{~m}^{-2}$ emitted to the atmosphere as $\mathrm{N}_{2} \mathrm{O}$ and $\mathrm{N}_{2}$ during the first year after appli- 
cation (Figure 5c). However, no fertilizer $\mathrm{N}$ was emitted thereafter, as was also found from $\mathrm{N}_{2} \mathrm{O}$ flux measurements taken during 2008 at the BC-DF49 site [Jassal et al., 2010]. Most of the leaching loss modeled in 2007 occurred under heavier rainfall after mid-October 2007 when plant growth and hence uptake had slowed (Figure 3 ). This loss was larger than one of $0.4 \mathrm{~g} \mathrm{~N} \mathrm{~m}^{-2}$ measured by Flint et al. [2008], most of which also occurred after mid-October, following a spring application of $22.4 \mathrm{~g} \mathrm{~N} \mathrm{~m}^{-2}$ as urea to a Douglas fir stand in nearby Washington State under climate conditions similar to those at BC-DF49. Substantial downward water movement occurs through the soil profile with heavier rainfall and cooler weather after mid-October in the Pacific Northwest. These leaching losses would thus represent most of the residual mineral $\mathrm{N}$ not taken up during the previous summer growing season, indicating that most fertilizer $\mathrm{N}$ was taken up soon after application at both sites, but perhaps more so in the study of Flint et al. [2008].

[47] The fraction of fertilizer $\mathrm{N}$ emitted as $\mathrm{N}_{2} \mathrm{O}$, or emission coefficient EF, during the first year after the urea application on 11 April in the model (3.74\%) and in the field study $(5.2 \%)$ (Figure 5$)$ were larger than ones measured in other studies of fertilizer application in forests. Sitaula et al. [1995b] calculated an annual EF of $1.7 \%$ in boreal pine by extrapolating 1 month of measurements. Matson et al. [1992] calculated an annual EF of $0.35 \%$ in Douglas fir from a few measurements during one growing season. In both these experiments, $\mathrm{N}$ was applied as ammonium nitrate, only one half of which would contribute to $\mathrm{N}_{2} \mathrm{O}$ emissions through nitrification. However, Brumme and Beese [1992] measured a similar annual EF of $1.6 \%$ in an acidic beech soil from five measurements per day with automated chambers following application of ammonium sulphate. The EFs modeled and measured in this study were also larger than those commonly measured or modeled in arable soils [e.g., Grant et al., 2006b].

[48] The large $\mathrm{N}_{2} \mathrm{O}$ emissions modeled after fertilization in this study were attributed mostly to chemodenitrification of $\mathrm{NO}_{2}^{-}$from nitrification $(70 \%)$, rather than to biological reduction of $\mathrm{NO}_{2}^{-}$from nitrification and denitrification $(30 \%)$. These emissions were driven by the low $\mathrm{pH}$ of Douglas fir litter (4.75) to which the fertilizer was applied (equation (A5a)). However, the parameterization of chemodenitrification in the model, while based on literature values derived from laboratory incubations (equations (A5b) and $(\mathrm{A} 5 \mathrm{c})$ ), needs further testing in field studies. Nonetheless the lower $\mathrm{pH}$ of forest soils is known to favor production of $\mathrm{N}_{2} \mathrm{O}$ over $\mathrm{NO}_{3}^{-}$during nitrification [Martikainen and de Boer, 1993; Sitaula et al., 1995a]. Consequently raising forest soil $\mathrm{pH}$ from 4.5 to 6.5 by liming has been found to reduce $\mathrm{N}_{2} \mathrm{O}$ emissions substantially [Brumme and Beese, 1992]. $\mathrm{N}_{2} \mathrm{O}$ emissions from coniferous forest soils may therefore be more sensitive to $\mathrm{N}$ additions from fertilizer or deposition than are those from arable soils with generally higher $\mathrm{pH}$ [Sitaula et al., 1995b]. The possibility of larger $\mathrm{N}_{2} \mathrm{O}$ EFs for fertilizer applications on forest soils with lower $\mathrm{pH}$ needs to be examined in further studies, given the rising use of fertilizer in forest production.

\subsection{Net $\mathrm{CO}_{2}$-Equivalent Exchange From Fertilizer $\mathrm{N}$}

[49] Fertilization of mature Douglas fir stands would typically occur 10-12 years before harvesting (although it may be done earlier) so that net GHG exchange attributed to fertilizer application might be assessed over this period. After 11 years, a total $\mathrm{C}$ sequestration of $1045 \mathrm{~g} \mathrm{C} \mathrm{m}^{-2}$ in the model was attributed to the $20 \mathrm{~g} \mathrm{~N} \mathrm{~m}^{-2}$ of fertilizer applied on 13 January 2007 (Figures 6b and 6c). Of this amount, only $48 \mathrm{~g} \mathrm{C} \mathrm{m}^{-2}$ was sequestered in below-ground pools (root, litter, soil) that would remain on site after harvest (Figure 6c). An additional $71 \mathrm{~g} \mathrm{C} \mathrm{m}^{-2}$ was sequestered as foliage, some of which could be lost at harvest, depending on logging practices. Most of these pools would be respired after harvest, and only a fraction, depending on clay content, would be stabilized in long-term humus pools. The remaining $926 \mathrm{~g} \mathrm{C} \mathrm{m}^{-2}$ in the model was sequestered as wood, the duration of which would depend on uses of the wood product.

[50] This sequestration had a direct cost of $0.60 \mathrm{~g} \mathrm{~N} \mathrm{~m}^{-2}$ or $78 \mathrm{~g} \mathrm{C} \mathrm{m}^{-2}$ equivalent from $\mathrm{N}_{2} \mathrm{O}$ emission and indirect costs of $17 \mathrm{~g} \mathrm{C} \mathrm{m}^{-2}$ from fertilizer transport and application [Jassal et al., 2008] and a further $2.7 \mathrm{~g} \mathrm{C} \mathrm{m}^{-2}$ equivalent through $\mathrm{N}_{2} \mathrm{O}$ emission from fertilizer $\mathrm{N}$ leached to ground or surface water. These costs offset $\mathrm{C}$ sequestration in all below-ground pools and most of that in foliage for the 11 years after application, so that any net gain in sequestration from this fertilizer application would depend entirely on the accounting of $\mathrm{C}$ from harvested wood products.

\section{Appendix A}

\section{A1. Urea Hydrolysis}

$[51]$

$$
\begin{array}{r}
\mathrm{CO}\left(\mathrm{NH}_{2}\right)_{2_{l}}+\mathrm{H}_{2} \mathrm{O} \rightarrow \mathrm{CO}_{2_{l}}+2 \mathrm{NH}_{3_{l}} \\
{\left[\mathrm{NH}_{4_{l}}^{+}\right] \leftrightarrow\left[\mathrm{NH}_{3 \mathrm{~s}_{l}}\right]+\left[H_{l}^{+}\right] \quad p K_{\mathrm{a}}=9.25}
\end{array}
$$

\section{A2. Mineralization-Immobilization}

[52]

$U_{\mathrm{NH}_{4 i, l, m, j}}=\left(M_{\mathrm{C}_{i, l, m, j}} C_{\mathrm{N}_{j}}-M_{\mathrm{N}_{i, l, m, j}}\right)$ (mineralization) $\quad U_{\mathrm{NH}_{4}}<0$

$$
\begin{aligned}
& U_{\mathrm{NH}_{4 i, l, m, j}}=\min \left\{\left(M \mathrm{C}_{i, l, m, j} C_{\mathrm{N}_{j}}-M_{\mathrm{N}_{i, l, m, j}}\right),\right. \\
& U_{\mathrm{NH}_{4}}^{\prime} A_{i, l, m, j}\left(\left[\mathrm{NH}_{4 i, l, m, j}^{+}\right]-\left[\mathrm{NH}_{4 \mathrm{mn}}^{+}\right]\right) \\
& \left.\quad /\left(\left[\mathrm{NH}_{4 i, l, m, j}^{+}\right]-\left[\mathrm{NH}_{4 \mathrm{mn}}^{+}\right]+K_{\mathrm{NH}_{4}}\right)\right\} \quad U_{\mathrm{NH}_{4}}>0 \\
& U_{\mathrm{NO}_{3 i, l, m, j}}=\min \left\{\left(M_{\mathrm{C}_{i, l, m, j}} C_{\mathrm{N}_{j}}-\left(M_{\mathrm{N}_{i, l, m, j}}+U_{\mathrm{NH}_{4 i, l, m, j}}\right)\right),\right. \\
& U_{\mathrm{NO}_{3}}^{\prime} A_{i, l, m, j}\left(\left[\mathrm{NO}_{3 i, l, m, j}^{-}\right]-\left[\mathrm{NO}_{3 \mathrm{mn}}^{-}\right]\right) \\
& \left.\quad /\left(\left[\mathrm{NO}_{3 i, l, m, j}^{-}\right]-\left[\mathrm{NO}_{3 \mathrm{mn}}^{-}\right]+K_{\mathrm{NO}_{3}}\right)\right\} \quad U_{\mathrm{NO}_{3}}>0
\end{aligned}
$$




\section{A3. Nitrification}

[53]

$$
\begin{aligned}
& X_{\mathrm{NH}_{3, l, l}}=X_{\mathrm{NH}_{3}}^{\prime} M_{\mathrm{C}_{i, l, n, a}}\left\{\left[\mathrm{NH}_{\left.3 \mathrm{~s}_{l}\right]}\right] /\left(\left[\mathrm{NH}_{3 \mathrm{~s}_{l}}\right]+K_{\mathrm{NH}_{3}}\right)\right\} \\
& \cdot\left\{\left[\mathrm{CO}_{2 \mathrm{~s}_{l}}\right] /\left(\left[\mathrm{CO}_{2 \mathrm{~s}_{l}}\right]+K_{\mathrm{CO}_{2}}\right)\right\} f_{\mathrm{t}_{\mathrm{s}}} f_{\mathrm{O}_{2} l} \\
& X_{\mathrm{NO}_{2 i, l, o}}=X_{\mathrm{NO}_{2}}^{\prime} M_{\mathrm{C}_{i, l, o,}}\left\{\left[\mathrm{NO}_{2_{l}}^{-}\right] /\left(\left[\mathrm{NO}_{2_{l}}^{-}\right]+K_{\mathrm{NO}_{2 o}}\right)\right\} \\
& \cdot\left\{\left[\mathrm{CO}_{2 \mathrm{~s}_{l}}\right] /\left(\left[\mathrm{CO}_{2 \mathrm{~s}_{l}}\right]+K_{\mathrm{CO}_{2}}\right)\right\} f_{\mathrm{t}_{\mathrm{s}}} f_{\mathrm{O}_{2} f_{l}} f_{\mathrm{i}_{l}} \\
& f_{\mathrm{i} l}=1.0 /\left\{\left(1.0+\left[\mathrm{NH}_{3 \mathrm{~S}_{l}}\right] / K_{\mathrm{iNH}_{3}}\right)\left(1.0+\left[\mathrm{HNO}_{2_{l}}\right] / K_{\mathrm{iHNO}_{2}}\right)\right\}
\end{aligned}
$$

$$
\begin{aligned}
R_{\mathrm{NO}_{2 i, l, n}}= & R_{\mathrm{NO}_{2 i, l, n}^{\prime}}^{\prime}\left\{\left[\mathrm{NO}_{2_{l}}^{-}\right] /\left(\left[\mathrm{NO}_{2_{l}}^{-}\right]+K_{\mathrm{NO}_{2 n}}\right)\right\} \\
& \cdot\left\{\left[\mathrm{CO}_{\left.2 \mathrm{~s}_{l}\right]}\right] /\left(\left[\mathrm{CO}_{2_{\mathrm{s}} l}\right]+K_{\mathrm{CO}_{2}}\right)\right\}
\end{aligned}
$$

\section{A4. Biological Denitrification}

[54]

$$
\begin{gathered}
R_{\mathrm{NO}_{3} i, l, d}=R_{\mathrm{NO}_{3} i, l, d}^{\prime}\left[\mathrm{NO}_{3_{l}}^{-}\right] /\left(\left[\mathrm{NO}_{3_{l}}^{-}\right]+K_{\mathrm{NO}_{3}}\right) \\
R_{\mathrm{NO}_{2} i, l, d}=\left(R_{\mathrm{NO}_{3} i, l, d}^{\prime}-R_{\mathrm{NO}_{3} i, l, d}\right)\left[\mathrm{NO}_{2}^{-}\right] /\left(\left[\mathrm{NO}_{2}^{-}\right]+K_{\mathrm{NO}_{2} d}\right)
\end{gathered}
$$

$$
\begin{aligned}
R_{\mathrm{N}_{2} \mathrm{O} i, l, d}= & 2\left(R_{\mathrm{NO}_{3} i, l, d}^{\prime}-R_{\mathrm{NO}_{3} i, l, d}-R_{\mathrm{NO}_{2} i, l, d}\right) \\
& \cdot\left[\mathrm{N}_{2} \mathrm{O}_{l}\right] /\left(\left[\mathrm{N}_{2} \mathrm{O}_{l}\right]+K_{\mathrm{N}_{2} \mathrm{O}}\right)
\end{aligned}
$$

\section{A5. Chemodenitrification}

[55]

$$
\begin{gathered}
{\left[\mathrm{HNO}_{2 l}\right] \leftrightarrow\left[\mathrm{NO}_{2 l}^{-}\right]+\left[\mathrm{H}_{l}^{+}\right] \quad p K_{\mathrm{a}}=3.3} \\
Q_{\mathrm{NO}_{2 l}}=Q_{\mathrm{NO}_{2}}^{\prime}\left[\mathrm{HNO}_{2_{l}}\right] \theta_{l l} f_{\mathrm{t}_{l} l} \\
Q_{\mathrm{N}_{2} \mathrm{O}_{l}}=f_{\mathrm{N}_{2} \mathrm{O}} Q_{\mathrm{NO}_{2 l}}
\end{gathered}
$$

\section{A6. Root and Mycorrhizal Uptake}

[56]

$$
\begin{gathered}
U_{\mathrm{NH}_{4 s, l, r}=\{} U_{\mathrm{w}_{s, l, r}}\left[\mathrm{NH}_{4 l]}^{+}\right]+2 \pi L_{s, l, r} D_{\mathrm{eNH}_{4}}\left(\left[\mathrm{NH}_{4 l}^{+}\right]-\left[\mathrm{NH}_{4 s, l, r}^{+}\right]\right) \\
\left./ \ln \left(d_{s, l, r} / r_{s, l, r}\right)\right\} f_{\mathrm{t}_{\mathrm{s} l}} \\
=U_{\mathrm{NH}_{4}}^{\prime} A_{s, l, r}\left(\left[\mathrm{NH}_{4 s, l, r}^{+}\right]-\left[\mathrm{NH}_{4 \mathrm{mn}}^{+}\right]\right) \\
/\left(\left[\mathrm{NH}_{4 s, l, r}^{+}\right]-\left[\mathrm{NH}_{4 \mathrm{mn}}^{+}\right]+K_{\mathrm{NH}_{4}}\right) f_{\mathrm{t}_{\mathrm{s} l}}
\end{gathered}
$$

$$
\begin{gathered}
U_{\mathrm{NO}_{3 s, l, r}}=\left\{U_{\mathrm{w}_{s, l, r}}\left[N O_{3 l}^{-}\right]+2 \pi L_{s, l, r} D_{\mathrm{eNO}_{3}}\left(\left[N O_{3 l}^{-}\right]-\left[N O_{3 s, l, r}^{-}\right]\right)\right. \\
\left.\quad / \ln \left(d_{s, l, r} / r_{s, l, r}\right)\right\} f_{\mathrm{t}^{l} l} \\
=U_{\mathrm{NO}_{3}}^{\prime} A_{s, l, r}\left(\left[\mathrm{NO}_{3 s, l, r}^{-}\right]-\left[\mathrm{NO}_{3 \mathrm{mn}}^{-}\right]\right) \\
\quad /\left(\left[\mathrm{NO}_{3 s, l, r}^{-}\right]-\left[\mathrm{NO}_{3 \mathrm{mn}}^{-}\right]+K_{\mathrm{NO}_{3}}\right) f_{\mathrm{t}_{\mathrm{s} l}}
\end{gathered}
$$

\section{A7. Plant Assimilation}

[57]

$$
\begin{gathered}
\sigma_{\mathrm{C}_{s, l, r}} / M_{\mathrm{C}_{s, l, r}}+T_{\mathrm{C}_{s, l, r}}=\sigma_{\mathrm{C}_{s, b}} / M_{\mathrm{C}_{s, b}}-T_{\mathrm{C}_{s, l, r}} \\
\sigma_{\mathrm{N}_{s, l, r}} / \sigma_{\mathrm{C}_{s, l, r}}-T_{\mathrm{N}_{s, l, r}}=\sigma_{\mathrm{N}_{s, b}} / \sigma_{\mathrm{C}_{s, b}}+T_{\mathrm{N}_{s, l, r}} \\
\sigma_{\mathrm{N} s, l, r(t)}=\sigma_{\mathrm{N} s, l, r(t-1)}+U_{\mathrm{NH}_{4 s, l, r}}+U_{\mathrm{NO}_{3 s, l, r}}-T_{\mathrm{N}_{s, l, r}}-G_{\mathrm{N}_{s, l, r}} \\
\sigma_{\mathrm{N}_{s, b(t)}}=\sigma_{\mathrm{N} s, b(t-1)}+\sum_{l} T_{\mathrm{N}_{s, l, r}}-G_{\mathrm{N}_{s, b}}
\end{gathered}
$$

$$
\begin{aligned}
G_{\mathrm{N}_{s, l, r}}= & \delta M_{\mathrm{N}_{s, b}} / \delta M_{\mathrm{C}_{s, b}}=\delta M_{\mathrm{C}_{s, b}} / \delta \mathrm{t} f\left(\operatorname { m i n } \left\{\sigma_{\mathrm{N}_{s, b}} /\left(\sigma_{\mathrm{N}_{s, b}}+\sigma_{\mathrm{C}_{s, b}} / K_{\mathrm{i} \sigma_{\mathrm{N}}}\right)\right.\right. \\
& \left.\left.\cdot \sigma_{\mathrm{P}_{s, b}} /\left(\sigma_{\mathrm{P}_{s, b}}+\sigma_{\mathrm{C}_{s, b}} / K_{\mathrm{i} \sigma_{\mathrm{P}}}\right)\right\}\right)
\end{aligned}
$$

$$
G P P_{s}=\sum_{b} \sum_{l} \sum_{k} \sum_{x} \sum_{y} \sum_{z} \min \left\{V_{\mathrm{b}_{s, b, l, k, x, y, z}}, V_{\mathrm{j}_{s, b, l, k, x, y, z}}\right\}
$$

$$
\begin{aligned}
V_{\mathrm{bs}, b, l, k, x, y, z}= & V_{\mathrm{bmax}_{s, b, k}}\left(C_{\mathrm{cs}, b, l, k, x, y, z}-\Gamma_{s, b, k}\right) \\
& /\left(C_{\mathrm{cs}, b, l, k, x, y, z}+K_{\mathrm{CO}_{2 s}}\right) f_{\psi_{s}} f_{\mathrm{t}_{\mathrm{bs}}} f_{\mathrm{N}_{s, b}}
\end{aligned}
$$

$$
\begin{gathered}
V_{\mathrm{js}, b, l, k, x, y, z}=\left(\varepsilon I_{s, l, x, y, z}+V_{\mathrm{jmax}_{s, b, k}}-\left(\left(\varepsilon I_{i, l, x, y, z}+V_{\mathrm{jmax}_{s, b, k}}\right)^{2}\right.\right. \\
\left.-4 \alpha \varepsilon I_{s, l, x, y, z} V_{\mathrm{jmax}_{s, b, k}}\right)^{0.5} /(2 \alpha) Y_{s, b l l, k, x, y, z} f_{\psi_{s}} f_{\mathrm{t}_{\mathrm{j} s}} f_{\mathrm{N}_{s, b}} \\
V_{\mathrm{bmax}_{s, b, k}}=V_{\mathrm{b}_{s}}^{\prime} N_{\text {rubisco }_{s}} M_{\mathrm{N}_{s, b, k}} / A_{s, b, k} \\
V_{\mathrm{jmax}_{s, b, k}}=V_{\mathrm{j}_{s}^{\prime}} N_{\text {chlorophyll }_{s}} M_{\mathrm{N}_{s, b, k}} / A_{s, b, k}
\end{gathered}
$$

$$
f_{\mathrm{N}_{s, b}}=\min \left\{\sigma_{\mathrm{N}_{s, b}} /\left(\sigma_{\mathrm{N}_{s, b}}+\sigma_{\mathrm{C}_{s, b}} / K_{\mathrm{i} \sigma_{\mathrm{N}}}\right), \sigma_{\mathrm{P}_{s, b}} /\left(\sigma_{\mathrm{P}_{s, b}}+\sigma_{\mathrm{C}_{s, b}} / K_{\mathrm{i} \sigma_{\mathrm{P}}}\right)\right\}
$$

\section{Notation}

A microbial or root surface area, equal to $4 \pi r^{2} N$ (mic.) and $\pi r^{2} L$ (roots) (equations (A2a)-(A2c), (A6a)-(A6d), and (A7a)-(A7k)) $\left(\mathrm{m}^{2} \mathrm{~m}^{-2}\right)$. 
$\alpha$ shape parameter for response of $V_{\mathrm{j}}$ to $I$, equal to 0.7 .

$C_{\mathrm{c}}$ chloroplast $\left[\mathrm{CO}_{2}\right]$ in equilibrium with $C_{\mathrm{i}}$ (equation $(\mathrm{A} 7 \mathrm{~g}))(\mu \mathrm{M})$.

$\left[\mathrm{CO}_{2 \mathrm{~S}}\right] \quad \mathrm{CO}_{2}$ concentration in soil solution (equations (A3a), (A3b), and (A3d)) (g C m $\left.{ }^{-3}\right)$.

$C_{\mathrm{N} j} \quad$ maximum ratio of $\mathrm{N}$ to $\mathrm{C}$ in $M$, equal to 0.22 and 0.13 for labile and resistant $j$ (equations (A2a), (A2b), and (A2c)) ( $\left.\mathrm{g} \mathrm{N} \mathrm{g} \mathrm{C}^{-1}\right)$.

$D_{\mathrm{eNH}_{4}} \quad$ effective dispersivity-diffusivity of $\mathrm{NH}_{4}^{+}$during root uptake (equation (A6a)) $\left(\mathrm{m}^{2} \mathrm{~h}^{-1}\right)$.

$d_{s, z} \quad$ half distance between adjacent roots assumed equal to uptake path length, equal to $\left(\pi L_{s, l, r} /\right.$ $\Delta \mathrm{z})^{-1 / 2}$ (equations (A6a) and (A6c)) (m)

$\varepsilon \quad$ quantum yield, equal to 0.40 (equation (A7h)) $\left(\mu \mathrm{mol} \mathrm{e}^{-} \mu\right.$ mol quanta $\left.{ }^{-1}\right)$.

$f_{\mathrm{i}}$ function for inhibition of $X_{\mathrm{NO} 2}$ by $\mathrm{NH}_{3}$ and $\mathrm{HNO}_{2}$ (equations (A3b) and (A3c)).

$f_{\mathrm{N}}$ nutrient inhibition of $V_{\mathrm{b}}$, (equations (A7g), (A7h), and (A7k))

$f_{\mathrm{N}_{2} \mathrm{O}} \quad$ fraction of $Q_{\mathrm{NO} 2}$ released as $Q_{\mathrm{N} 2 \mathrm{O}}$, equal to 0.1 [Mørkved et al., 2007] (equation (A5c)).

$f_{\mathrm{O} 2}$ ratio of $\mathrm{O}_{2}$ supply to demand at ambient $\left[\mathrm{O}_{2}\right]$ (equations (A3a) and (A3b)).

$f_{\psi}$ nonstomatal water effect on $V_{\mathrm{b}}, V_{\mathrm{j}}$ [Grant and Flanagan, 2007] (equations (A7g) and (A7h)).

$f_{\mathrm{t}_{\mathrm{s}}} \quad$ Arrhenius temperature function for soil processes (equations (A3a)-(A3d), (A5a)-(A5c), and (A6a)-(A6d))

$f_{\mathrm{t}_{\mathrm{b}}} \quad$ Arrhenius temperature function for $V_{\mathrm{b}}$ [Bernacchi et al., 2003] (equation (A7g)).

$f_{\mathrm{t}_{\mathrm{j}}} \quad$ Arrhenius temperature function for $V_{\mathrm{j}}$ [Bernacchi et al., 2003] (equation (A7h))

$G_{\mathrm{N}} \sigma_{\mathrm{N}}$ consumed in growth (equations (A7c), (A7d), and (A7e)) $\left(\mathrm{g} \mathrm{m}^{-2} \mathrm{~h}^{-1}\right)$.

$\Gamma \quad \mathrm{CO}_{2}$ compensation point (equation (A7g)) $(\mu \mathrm{M})$.

$\left[\mathrm{H}^{+}\right]$hydrogen ion concentration (equations (A1c) and (A5a)) (mol L $\left.{ }^{-1}\right)$.

$I \quad$ irradiance (equation (A7h)) $\left(\mu \mathrm{mol} \mathrm{m}{ }^{-2} \mathrm{~s}^{-1}\right)$.

$K_{\mathrm{CO}_{2}}$ Michaelis-Menten constant for $\mathrm{CO}_{2}$ reduction, equal to 0.15 (equations (A3a), (A3b), and (A3d)) $\left(\mathrm{g} \mathrm{C} \mathrm{m}^{-3}\right)$.

$K_{\mathrm{CO}_{2}}$ Michaelis-Menten constant for $\mathrm{CO}_{2}$ fixation (equation $(\mathrm{A} 7 \mathrm{~g}))(\mu \mathrm{M})$.

$K_{\mathrm{iHNO}_{2}} \quad\left[\mathrm{HNO}_{2}\right]$ at $1 / 2$ inhibition of $X_{\mathrm{NO} 2}$, equal to 25.0 [Blackburne et al., 2007] (equation (A3c) $\left(\mathrm{g} \mathrm{N} \mathrm{m}^{-3}\right)$.

$K_{\mathrm{iNH}_{3}} \quad\left[\mathrm{NH}_{3}\right]$ at $1 / 2$ inhibition of $X_{\mathrm{NO} 2}$, equal to 10.0 [Blackburne et al., 2007] (equation (A3c) $\left(\mathrm{g} \mathrm{N} \mathrm{m}^{-3}\right)$.

$K_{\mathrm{i} \sigma_{\mathrm{N}}}$ inhibition constant for $\sigma_{\mathrm{C} i, j}$ versus $\sigma_{\mathrm{N} i, j}$, equal to 100 [Grant, 1998] (equations (A7e) and (A7k)) ( $\left.\mathrm{g} \mathrm{C} \mathrm{g} \mathrm{N}^{-1}\right)$.

$K_{\mathrm{i} \sigma_{\mathrm{P}}} \quad$ inhibition constant for $\sigma_{\mathrm{C} i, j}$ versus $\sigma_{\mathrm{P} i, j}$, equal to 1000 [Grant, 1998] (equations (A7e) and (A7k)) ( $\left.\mathrm{g} \mathrm{C} \mathrm{g} \mathrm{P}^{-1}\right)$.

$K_{\mathrm{NH}_{3}} \quad$ Michaelis-Menten constant for $X_{\mathrm{NH} 3}$, equal to $2.0 \times 10^{-4}$ [Stark and Firestone, 1996] (equation $(\mathrm{A} 3 \mathrm{a}))\left(\mathrm{g} \mathrm{N} \mathrm{m}^{-3}\right)$.
$K_{\mathrm{NH}_{4}} \quad$ Michaelis-Menten constant for $I_{\mathrm{NH} 4}$ or $U_{\mathrm{NH} 4}$, equal to 0.40 [Barber and Silberbush, 1984] (equations (A2b) and (A6b)) $\left(\mathrm{g} \mathrm{N} \mathrm{m}^{-3}\right)$

$K_{\mathrm{NO}_{3}} \quad$ Michaelis-Menten constant for $I_{\mathrm{NO} 3}$ or $U_{\mathrm{NO} 3}$, equal to 0.35 [Barber and Silberbush, 1984] (equations (A2c) and (A6c)) $\left(\mathrm{g} \mathrm{N} \mathrm{m}^{-3}\right)$

$K_{\mathrm{NO}_{2 d}} \quad$ Michaelis-Menten constant for $R_{\mathrm{NO} 2}$ by denitrifiers, equal to 2.5 [Yoshinari et al., 1977] (equation (A4b)) $\left(\mathrm{g} \mathrm{N} \mathrm{m}^{-3}\right)$.

$K_{N_{2 n} n} \quad$ Michaelis-Menten constant for $R_{\mathrm{NO} 2}$ by nitrifiers, equal to 2.5(equation (A3d)) $\left(\mathrm{g} \mathrm{N} \mathrm{m}^{-3}\right)$.

$K_{\mathrm{NO}_{2} \mathrm{O}} \quad$ Michaelis-Menten constant for $X_{\mathrm{NO} 2}$, equal to 0.7 [Blackburne et al., 2007] (equation (A3b)) (g N m${ }^{-3}$ ).

$K_{\mathrm{NO}_{3}} \quad$ Michaelis-Menten constant for $R_{\mathrm{NO} 3}$, equal to 2.5 [Yoshinari et al., 1977] (equation (A4a)) (g N m${ }^{-3}$ ).

$K_{\mathrm{N}_{2} \mathrm{O}}$ Michaelis-Menten for $R_{\mathrm{N} 2 \mathrm{O}}$, equal to 2.5 [Yoshinari et al., 1977] (equation (A4c)) $\left(\mathrm{g} \mathrm{N} \mathrm{m}^{-3}\right)$.

$k_{\mathrm{T}} \quad$ rate constant for $T_{\mathrm{N}}$ (equation $\left.(\mathrm{A} 7 \mathrm{~b})\right)\left(\mathrm{h}^{-1}\right)$.

$L$ root length (equations (A6a) and (A6c)) $\left(\mathrm{m} \mathrm{m}^{-2}\right.$ ).

$M_{\mathrm{C}}$ microbial, root or shoot biomass $\mathrm{C}$ (equations (A2a)-(A2c), (A1a), (A1b), (A3), (A7a), and (A7e)) $\left(\mathrm{g} \mathrm{C} \mathrm{m}^{-2}\right)$.

$M_{\mathrm{N}}$ microbial, root or shoot biomass $\mathrm{N}$ (equations (A2a)-(A2c), (A1a)-(A1b), (A3a)-(A3d), and (A7e)) $\left(\mathrm{g} \mathrm{N} \mathrm{m}^{-2}\right)$.

$N$ microbial number $\left(\mathrm{m}^{-2}\right)$.

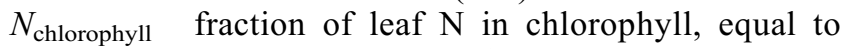
0.025 (equation $(\mathrm{A} 7 \mathrm{j})$ ).

$N_{\text {rubisco }}$ fraction of leaf $\mathrm{N}$ in rubisco, equal to 0.125 (equation (A7i))

$\left[\mathrm{NH}_{4 \mathrm{mn}}^{+}\right] \quad\left[\mathrm{NH}_{4}^{+}\right]$below which $U_{\mathrm{NH} 4}=0$, equal to 0.0125 [Barber and Silberbush, 1984] (equations (A2b) and (A6b)) $\left(\mathrm{g} \mathrm{N} \mathrm{m}^{-3}\right)$.

$\left[\mathrm{NO}_{3-\mathrm{mn}}\right] \quad\left[\mathrm{NO}_{3}^{-}\right]$below which $U_{\mathrm{NO} 3}=0$, equal to 0.03 [Barber and Silberbush, 1984] (equations (A2c) and (A6c)) $\left(\mathrm{g} \mathrm{N} \mathrm{m}^{-3}\right)$.

$Q_{\mathrm{NO}_{2}} \quad \mathrm{NO}_{2}^{-}$reduction by chemodenitrification (equations (A5b) and (A5c)) $\left(\mathrm{g} \mathrm{N} \mathrm{m}^{-2} \mathrm{~h}^{-1}\right)$.

$Q^{\prime} \mathrm{NO}_{2}$ rate constant for decomposition of $\mathrm{HNO}_{2}$ at $25^{\circ} \mathrm{C}$, equal to 0.075 [Cleemput and Samater, 1996] (equation (A5b)) $\left(\mathrm{h}^{-1}\right)$.

$Q_{\mathrm{N}_{2} \mathrm{O}} \quad \mathrm{N}_{2} \mathrm{O}$ production by chemodenitrification (equation (A5c)) $\left(\mathrm{g} \mathrm{N} \mathrm{m}^{-2} \mathrm{~h}^{-1}\right)$.

$\theta$ soil water content (equation (A5b)) $\left(\mathrm{m}^{3} \mathrm{~m}^{-3}\right)$.

$R_{\mathrm{NO}_{2}} \quad \mathrm{NO}_{2}^{-}$reduction under ambient $\left[\mathrm{NO}_{2}^{-}\right.$] (equations (A3d) and (A4b)) $\left(\mathrm{g} \mathrm{N} \mathrm{m}^{-2} \mathrm{~h}^{-1}\right)$.

$R_{\mathrm{NO}_{2}}^{\prime} \quad R_{\mathrm{NO} 2}$ under nonlimiting $\left[\mathrm{NO}_{2}^{-}\right.$] (equation (A3d)) $\left(\mathrm{g} \mathrm{N} \mathrm{m}^{-2} \mathrm{~h}^{-1}\right)$.

$R_{\mathrm{NO}_{3}} \quad \mathrm{NO}_{3}^{-}$reduction under ambient $\left[\mathrm{NO}_{3}^{-}\right]$ (equations (A4a), (A4b), and (A4c)) $\left(\mathrm{g} \mathrm{N} \mathrm{m}^{-2} \mathrm{~h}^{-1}\right)$.

$R_{\mathrm{NO}_{3}}^{\prime} \quad R_{\mathrm{NO} 3}$ under nonlimiting $\left[\mathrm{NO}_{3}^{-}\right]$(equations (A4a), (A4b), and (A4c)) ( $\left.\mathrm{g} \mathrm{N} \mathrm{m}^{-2} \mathrm{~h}^{-1}\right)$.

$R_{\mathrm{N}_{2} \mathrm{O}} \quad \mathrm{N}_{2} \mathrm{O}$ reduction under ambient $\left[\mathrm{N}_{2} \mathrm{O}\right]$ (equation (A4c)) $\left(\mathrm{g} \mathrm{N} \mathrm{m}^{-2} \mathrm{~h}^{-1}\right)$.

$r$ radius of root or mycorrhizae, equal to $1.0 \times$ $10^{-3}, 5.0 \times 10^{-6}$ (equations (A6a) and (A6c)) (m).

$\sigma_{\mathrm{C}}$ nonstructural $\mathrm{C}$ (equations (A7a), (A7b), (A7e), and (A7k)) $\left(\mathrm{g} \mathrm{C} \mathrm{m}^{-2}\right)$.

$\sigma_{\mathrm{N}}$ nonstructural $\mathrm{N}$ (equations (A7b), (A7c), (A7d), (A7e), and (A7k)) $\left(\mathrm{g} \mathrm{N} \mathrm{m}^{-2}\right)$. 
$T_{\mathrm{C}}$ transfer of $\sigma_{\mathrm{C}}$ between shoot and root (equation (A7a)) $\left(\mathrm{g} \mathrm{N} \mathrm{m}^{-2} \mathrm{~h}^{-1}\right)$.

$T_{\mathrm{N}}$ transfer of $\sigma_{\mathrm{N}}$ between root and shoot (equations (A7b), (A7c), and (A7d)) $(\mathrm{g} \mathrm{N}$ $\left.\mathrm{m}^{-2} \mathrm{~h}^{-1}\right)$.

$U_{\mathrm{NH}_{4}} \quad \mathrm{NH}_{4}^{+}$uptake by microbial, root or mycorrhizal surfaces (equations (A2a)-(A2c), (A6a)-(A6d), and $(\mathrm{A} 7 \mathrm{c}))\left(\mathrm{g} \mathrm{N} \mathrm{m}^{-2} \mathrm{~h}^{-1}\right)$.

$U_{\mathrm{NH}_{4}}^{\prime}$ maximum $U_{\mathrm{NH} 4}$ at $25^{\circ} \mathrm{C}$ and nonlimiting $\mathrm{NH}_{4}^{+}$, equal to $5.0 \times 10^{-3}$ [Barber and Silberbush, 1984] (equations (A2b) and (A6b)) $\left(\mathrm{g} \mathrm{N} \mathrm{m}^{-2} \mathrm{~h}^{-1}\right.$ ).

$U_{\mathrm{NO}_{3}} \quad \mathrm{NO}_{3}^{-}$uptake by microbial, root or mycorrhizal surfaces (equations (A2a)-(A2c), (A6a)-(A6d), and $(\mathrm{A} 7 \mathrm{c}))\left(\mathrm{g} \mathrm{N} \mathrm{m}^{-2} \mathrm{~h}^{-1}\right)$.

$U_{\mathrm{NO}_{3}}^{\prime}$ maximum $U_{\mathrm{NO} 3}$ at $25^{\circ} \mathrm{C}$ and nonlimiting $\mathrm{NO}_{3}^{-}$, equal to $5.0 \times 10^{-3}$ [Barber and Silberbush, 1984] (equations (A2c) and (A6c)) $\left(\mathrm{g} \mathrm{N} \mathrm{m}^{-2} \mathrm{~h}^{-1}\right)$.

$U_{\mathrm{w}}$ water uptake by roots or mycorrhizae (equations (A6a) and (A6c)) $\left(\mathrm{m}^{3} \mathrm{~m}^{-2} \mathrm{~h}^{-1}\right)$.

$V_{\mathrm{b}} \quad \mathrm{CO}_{2}$-limited leaf carboxylation (equation (A7g)) $\left(\mu \mathrm{mol} \mathrm{m}^{-2} \mathrm{~s}^{-1}\right)$.

$V_{\mathrm{b}}{ }^{\prime} \quad$ specific rubisco carboxylation at $25^{\circ} \mathrm{C}$, equal to 45 [Farquhar et al., 1980] (equation (A7i)) $\left(\mu \mathrm{mol} \mathrm{g}^{-1}\right.$ rubisco s $\left.{ }^{-1}\right)$.

$V_{\text {bmax }} \quad V_{\mathrm{b}}$ at nonlimiting $\mathrm{CO}_{2}, \psi ;{ }_{\mathrm{c} i}, T_{c}$ and $\mathrm{N}, \mathrm{P}$ (equations (A7g) and (A7i)) $\left(\mu \mathrm{mol} \mathrm{m} \mathrm{s}^{-2} \mathrm{~s}^{-1}\right.$.

$V_{\mathrm{j}} \quad$ irradiance-limited carboxylation (equation (A7h) $\left(\mu \mathrm{mol} \mathrm{m}^{-2} \mathrm{~s}^{-1}\right)$.

$V_{\mathrm{j}}^{\prime} \quad$ specific chlorophyll $\mathrm{e}^{-}$transfer at $25^{\circ} \mathrm{C}$, equal to 450 [Farquhar et al., 1980] (equation (A7j)) ( $\mu \mathrm{mol} \mathrm{g}^{-1}$ chlorophyll s$\left.{ }^{-1}\right)$.

$V_{\text {jmax }} \quad V_{\mathrm{j}}$ at nonlimiting $\mathrm{CO}_{2}, \psi_{\mathrm{c} i}, T_{c}$ and N,P (equation (A7h)) $\left(\mu \mathrm{mol} \mathrm{m}{ }^{-2} \mathrm{~s}^{-1}\right)$.

$X_{\mathrm{NH}_{3}}^{\prime}$ specific $\mathrm{NH}_{3}$ oxidation at $25^{\circ} \mathrm{C}$ and nonlimiting $\left[\mathrm{O}_{2}\right]$, equal to 0.625 [Belser and Schmidt, 1980] (equation (A3a)) $\left(\mathrm{g} \mathrm{N} \mathrm{g}^{-1} \mathrm{M} \mathrm{h}^{-1}\right)$.

$X_{\mathrm{NH}_{3}} \quad \mathrm{NH}_{3}$ oxidation under ambient $T_{\mathrm{s}}$ and $\left[\mathrm{O}_{2}\right]$ (equation (A3a)) $\left(\mathrm{g} \mathrm{N} \mathrm{m}^{-2} \mathrm{~h}^{-1}\right)$.

$X_{\mathrm{NO}_{2}}^{\prime}$ specific $\mathrm{NO}_{2}^{-}$oxidation under at $25^{\circ} \mathrm{C}$ and nonlimiting $\left[\mathrm{O}_{2} \mathrm{~s}\right]$, equal to 0.75 [Blackburne et al., 2007] (equation (A3b)) $\left(\mathrm{g} \mathrm{C} \mathrm{m}^{-2} \mathrm{~h}^{-1}\right)$.

$X_{\mathrm{NO}_{2}} \quad \mathrm{NO}_{2}^{-}$oxidation under ambient temperature and $\left[\mathrm{O}_{2} \mathrm{~s}\right]$ (equation (A3b)) $\left(\mathrm{g} \mathrm{C} \mathrm{m}^{-2} \mathrm{~h}^{-1}\right)$.

Subscript

$a$ active component of $\mathrm{M}_{i, m}$

$b$ branch of plant species $s$.

$d$ heterotrophic denitrifier population (subset of $h$ ).

$h$ heterotrophic community (subset of $m$ ).

$i$ substrate-microbe complex.

$j$ kinetic components of $M$.

$k$ node of branch $b$.

$l$ soil, surface litter or canopy layer.

$m$ all microbial communities.

$n \quad$ autotrophic ammonia oxidizer population (subset of $m$ ).

$o \quad$ autotrophic nitrite oxidizer population (subset of $m$ ).

$r$ root or mycorrhizae population.

$s$ plant species.

$x$ leaf azimuth. $y \quad$ leaf inclination.

$z \quad$ leaf exposure (sunlit or shaded).

[58] Acknowledgments. The Canada Carbon Project is funded by the Canadian Foundation for Climate and Atmospheric Sciences (CFCAS). Computational facilities for ecosys were provided by the Westgrid highperformance computing infrastructure. We greatly appreciate the litterfall data provided by A. J. (Tony) Trofymow, Pacific Forest Center CFS, Victoria.

\section{References}

Aber, J. D., K. J. Nadelhoffer, P. Steudler, and J. M. Mellilo (1989), Nitrogen saturation of northern forest ecosystems, BioScience, 39, 378-386, doi: $10.2307 / 1311067$.

Adams, A. B., R. B. Harrison, R. S. Sletten, B. D. Strahm, E. C. Turnblom, and C. M. Jensen (2005), Nitrogen-fertilization impacts on carbon sequestration and flux in managed coastal Douglas fir stands of the Pacific Northwest, For. Ecol. Manage., 220, 313-325, doi:10.1016/j. foreco.2005.08.018

Barber, S. A., and M. Silberbush (1984), Plant root morphology and nutrient uptake, in Roots, Nutrient and Water Influx, and Plant Growth, ASA Spec. Publ., vol. 49, edited by S. A. Barber and D. R. Bouldin, pp. 6587, Soil Sci. Soc. of Am., Madison, Wis.

Bernacchi, C. J., C. Pimentel, and S. P. Long (2003), In vivo temperature response functions of parameters required to model RuBP-limited photosynthesis, Plant Cell Environ., 26, 1419-1430, doi:10.1046/j.00168025.2003.01050.x.

Belser, L. W., and E. L. Schmidt (1980), Growth and oxidation kinetics of the three genera of ammonia oxidizers, FEMS Microbiol. Lett., 7, 213216, doi:10.1111/j.1574-6941.1980.tb01628.x.

Berg, B., and C. McClaugherty (2003), Plant Litter: Decomposition, Humus Formation, Carbon Sequestration, Springer, Berlin.

Blackburne, R., V. M. Vadivelu, Z. Yuan, and J. Keller (2007), Kinetic characterisation of an enriched Nitrospira culture with comparison to Nitrobacter, Water Res., 41, 3033-3042, doi:10.1016/j.watres.2007. 01.043 .

Bowden, R. D., J. M. Melillo, P. D. Steudler, and J. D. Aber (1991), Effects of nitrogen additions on annual nitrous oxide fluxes from temperate forest soils in the northeastern United States, J. Geophys. Res., 96, 93219328, doi:10.1029/91JD00151.

Brumme, R., and F. Beese (1992), Effects of liming and nitrogen fertilization on emissions of $\mathrm{CO}_{2}$ and $\mathrm{N}_{2} \mathrm{O}$ from a temporate forest, J. Geophys. Res., 97(D12), 12,851-12,858, doi:10.1029/92JD01217.

Burton, A. J., K. S. Pregitzer, J. N. Crawford, G. P. Zogg, and D. R. Zak (2004), Simulated chronic NO3-deposition reduces soil respiration in northern hardwood forests, Global Change Biol., 10, 1080-1091, doi:10.1111/j.1365-2486.2004.00737.x

Cleemput, O., and A. H. Samater (1996), Nitrite in soils: Accumulation and role in the formation of gaseous N compounds, Fert. Res., 45, 81-89, doi:10.1007/BF00749884.

Edmonds, R. L., and T. Hsiang (1987), Forest floor and soil influence on response of Douglas fir to urea, Soil Sci. Soc. Am. J., 51, 1332-1337, doi:10.2136/sssaj1987.03615995005100050043x.

Ericsson, T., L. Rytter, and E. Vapaavuori (1996), Physiology of carbon allocation in trees, Biomass Bioenergy, 11, 115-127, doi:10.1016/ 0961-9534(96)00032-3.

Farquhar, G. D., S. von Caemmerer, and J. A. Berry (1980), A biochemical model of photosynthetic $\mathrm{CO}_{2}$ assimilation in leaves of $\mathrm{C}_{3}$ species, Planta, 149, 78-90, doi:10.1007/BF00386231.

Flint, C., A. Adams, B. Strahm, and R. Harrison (2008), Nitrogen Leaching from Douglas fir Forests after Urea Fertilization, J. Environ. Qual., 37, 1781-1788, doi:10.2134/jeq2007.0367.

Giardina, C. P., D. Binkley, M. G. Ryan, J. H. Fownes, and R. S. Senock (2004), Belowground carbon cycling in a humid tropical forest decreases with fertilization, Oecologia, 139, 545-550, doi:10.1007/s00442-0041552-0.

Gower, S. T., K. A. Vogt, and C. C. Grier (1992), Carbon dynamics of Rocky Mountain Douglas fir: Influence of water and nutrient availability, Ecol. Monogr., 62, 43-65, doi:10.2307/2937170.

Grant, R. F. (1993), Rhizodeposition by crop plants and its relationship to microbial activity and nitrogen distribution, Model. Geo-Biol. Processes, 2, 193-209.

Grant, R. F. (1994), Simulation of ecological controls on nitrification, Soil Biol. Biochem., 26, 305-315, doi:10.1016/0038-0717(94)90279-8.

Grant, R. F. (1995), Mathematical modelling of nitrous oxide evolution during nitrification, Soil Biol. Biochem., 27, 1117-1125, doi:10.1016/ 0038-0717(95)00038-G. 
Grant, R. F. (1998), Simulation in ecosys of root growth response to contrasting soil water and nitrogen, Ecol. Modell., 107, 237-264, doi:10.1016/S0304-3800(97)00221-4

Grant, R. F. (2004), Modelling topographic effects on net ecosystem productivity of boreal black spruce forests, Tree Physiol., 24, 1-18.

Grant, R. F., and E. Pattey (2003), Modelling variability in $\mathrm{N}_{2} \mathrm{O}$ emissions from fertilized agricultural fields, Soil Biol. Biochem., 35, 225-243, doi:10.1016/S0038-0717(02)00256-0.

Grant, R. F., and L. B. Flanagan (2007), Modeling stomatal and nonstomatal effects of water deficits on $\mathrm{CO}_{2}$ fixation in a semiarid grassland, $J$ Geophys. Res., 112, G03011, doi:10.1029/2006JG000302.

Grant, R. F., N. G. Juma, and W. B. McGill (1993a), Simulation of carbon and nitrogen transformations in soils: I. Mineralization, Soil Biol. Biochem., 25, 1317-1329, doi:10.1016/0038-0717(93)90046-E.

Grant, R. F., N. G. Juma, and W. B. McGill (1993b), Simulation of carbon and nitrogen transformations in soils. II. Microbial biomass and metabolic products, Soil Biol. Biochem., 25, 1331-1338, doi:10.1016/00380717(93)90047-F.

Grant, R. F., et al. (2001), $\mathrm{CO}_{2}$ effects on mass and energy exchange of wheat under different $\mathrm{N}$ fertilization: Model theory and testing with a Free Air $\mathrm{CO}_{2}$ Enrichment (FACE) experiment, Agron. J., 93, 638-649, doi:10.2134/agronj2001.933638x.

Grant, R. F., A. Arain, V. Arora, A. Barr, T. A. Black, J. Chen, S. Wang, F. Yuan, and Y. Zhang (2005), Intercomparison of techniques to mode high temperature effects on $\mathrm{CO}_{2}$ and energy exchange in temperate and boreal coniferous forests, Ecol. Modell., 188, 217-252, doi:10.1016/j. ecolmodel.2005.01.060.

Grant, R. F., T. A. Black, D. Gaumont-Guay, N. Kljun, A. G. Barr, K. Morgenstern, and Z. Nesic (2006a), Net ecosystem productivity of boreal aspen forests under drought and climate change: Mathematica modeling with ecosys, Agric. For. Meteorol., 140, 152-170, doi:10.1016/j.agrformet.2006.01.012.

Grant, R. F., E. M. Pattey, T. W. Goddard, L. M. Kryzanowski, and H. Puurveen (2006b), Modeling the effects of fertilizer application rate on nitrous oxide emissions from agricultural fields, Soil Sci. Soc. Am. $J .$, 70, 235-248, doi:10.2136/sssaj2005.0104.

Grant, R. F., et al. (2006c), Intercomparison of techniques to model water stress effects on $\mathrm{CO}_{2}$ and energy exchange in temperate and boreal deciduous forests, Ecol. Modell., 196, 289-312, doi:10.1016/j.ecolmodel. 2006.02.035.

Grant, R. F., T. J. Arkebauer, A. Dobermann, K. G. Hubbard, T. T. Schimelfenig, A. E. Suyker, S. B. Verma, and D. T. Walters (2007a), Net biome productivity of irrigated and rainfed maize-soybean rotations: Modeling versus measurements, Agron. J., 99, 1404-1423, doi:10.2134/ agronj2006.0308.

Grant, R. F., et al. (2007b), Net ecosystem productivity of boreal jack pine stands regenerating from clearcutting under current and future climates, Global Change Biol., 13, 1423-1440, doi:10.1111/j.1365-2486. 2007.01363.x.

Grant, R. F., T. A. Black, E. R. Humphreys, and K. Morgenstern (2007c), Changes in net ecosystem productivity with forest age following clearcutting of a coastal Douglas fir forest: Testing a mathematical model with eddy covariance measurements along a forest chronosequence, Tree Physiol., 27, 115-131.

Grant, R. F., A. G. Barr, T. A. Black, H. A. Margolis, A. L. Dunn, J. Metsaranta, and S. Wang (2009), Interannual variation in net ecosystem productivity of Canadian forests as affected by regional weather patterns-A Fluxnet-Canada synthesis, Agric. For. Meteorol., 149, 2022-2039, doi:10.1016/j.agrformet.2009.07.010.

Haynes, B. E., and S. T. Gower (1995), Belowground carbon allocation in unfertilized and fertilized red pine plantations in northern Wisconsin, Tree Physiol., 15, 317-325.

Holland, E. A., F. J. Dentener, B. H. Braswell, and J. M. Sulzman (1999), Contemporary and pre-industrial global reactive nitrogen budgets, Biogeochemistry, 46, 7-43, doi:10.1007/BF01007572.

Hopmans, P., and H. N. Chappell (1994), Growth response of young, thinned Douglas fir stands to nitrogen fertilizer in relation to soil properties and tree nutrition, Can. J. For. Res., 24(8), 1684-1688, doi:10.1139/ x94-217.

Humphreys, E. R. (2004), Net ecosystem production of three coastal Douglas fir stands at different stages of development after harvesting, Ph.D. thesis, 122 pp., Univ. of B. C., Vancouver, Canada.

Humphreys, E. R., T. A. Black, K. Morgenstern, T. Cai, G. B. Drewitt, Z. Nesic, and J. A. Trofymow (2006), Carbon dioxide fluxes in coastal Douglas fir stands at different stages of development after clearcut harvesting, Agric. For. Meteorol., 140, 6-22, doi:10.1016/j.agrformet. 2006.03 .018$.

Iivonen, S., R. Rikala, and E. Vapaavuori (2001), Seasonal root growth of Scots pine seedlings in relation to shoot phenology, carbohydrate status and nutrient supply, Can. J. For. Res., 31, 1569-1578, doi:10.1139/cjfr31-9-1569.

Iivonen, S., S. Kaakinen, A. Jolkkonen, E. Vapaavuori, and S. Linder (2006), Influence of long-term nutrient optimization on biomass, carbon, and nitrogen acquisition and allocation in Norway spruce, Can. J. For. Res., 36, 1563-1571, doi:10.1139/X06-035.

Jassal, R. S., T. A. Black, T. Cai, K. Morgenstern, Z. Li, D. GaumontGuay, and Z. Nesic (2007), Components of ecosystem respiration and an estimate of net primary productivity of an intermediate-aged Douglas fir stand, Agric. For. Meteorol., 144, 44-57, doi:10.1016/j.agrformet.2007.01.011

Jassal, R. S., T. A. Black, B. Z. Chen, R. Roy, Z. Nesic, D. L. Spittlehouse, and J. A. Trofymow (2008), $\mathrm{N}_{2} \mathrm{O}$ emissions and carbon sequestration in a nitrogen-fertilized Douglas fir stand, J. Geophys. Res., 113, G04013, doi:10.1029/2008JG000764.

Jassal, R. S., T. A. Black, T. Cai, G. Ethier, S. Pepin, C. Bruemmer, Z. Nesic, D. L. Spittlehouse, and J. A. Trofymow (2009), Impact of nitrogen fertilization on carbon and water balances in a chronosequence of three Douglas fir stands in the Pacific Northwest, Agric. For. Meteorol., doi:10.1016/j.agrformet.2009.10.005, in press.

Jassal, R. S., T. A. Black, J. A. Trofymow, R. Roy, and Z. Nesic (2010) Soil $\mathrm{CO}_{2}$ and $\mathrm{N}_{2} \mathrm{O}$ flux dynamics in a nitrogen-fertilized Pacific Northwest Douglas-fir stand, Geoderma, 157, 118-125, doi:10.1016/j.geoderma. 2010.04.002.

Johnson, D. W., and P. S. Curtis (2001), Effects of forest management on soil C and N storage: Meta analysis, For. Ecol. Manage., 140, 227-238, doi:10.1016/S0378-1127(00)00282-6.

Kaakinen, S., A. Jolkkonen, S. Iivonen, and E. Vapaavuori (2004), Growth, allocation and tissue chemistry of Picea abies seedlings affected by nutrient supply during the second growing season, Tree Physiol., 24, 707-719.

Lal, R. B., D. E. Kissel, M. L. Cabrera, and A. P. Schwab (1993), Kinetics of urea hydrolysis in wheat residue, Soil Biol. Biochem., 25, 1033-1036, doi:10.1016/0038-0717(93)90151-Z.

Martikainen, P. J., and W. de Boer (1993), Nitrous oxide production and nitrification in acidic soil from a Dutch coniferous forest, Soil Biol. Biochem., 25, 343-347, doi:10.1016/0038-0717(93)90133-V.

Matson, P. A., S. T. Gower, C. Volkmann, C. Billow, and C. C. Grier (1992), Soil nitrogen cycling and nitrous oxide flux in a Rocky Mountain Douglas fir forest: Effects of fertilization, irrigation and carbon addition, Biogeochemistry, 18, 101-117, doi:10.1007/BF00002705.

Mead, D. J., S. X. Chang, and C. M. Preston (2008), Recovery of ${ }^{15} \mathrm{~N}$-urea 10 years after application to a Douglas fir pole stand in coastal British Columbia, For. Ecol. Manage., 256, 694-701, doi:10.1016/j.foreco. 2008.05.022.

Meteorological Service of Canada (2004), Canadian Acid Deposition Science Assessment, Environ. Can., Ottawa.

Morgenstern, K., T. A. Black, E. R. Humphreys, T. J. Griffis, T. Cai, G. B Drewitt, D. Gaumont-Guay, and Z. Nesic (2004), Sensitivity and uncertainty of the carbon balance of a Pacific Northwest Douglas fir forest during an El Niño/La Niña cycle, Agric. For. Meteorol., 123, 201-219, doi:10.1016/j.agrformet.2003.12.003.

Mørkved, P. T., P. Dörsch, and L. R. Bakken (2007), The $\mathrm{N}_{2} \mathrm{O}$ product ratio of nitrification and its dependence on long-term changes in soil pH, Soil Biol. Biochem., 39, 2048-2057, doi:10.1016/j.soilbio. 2007.03.006.

Moyo, C. C., D. E. Kissel, and M. L. Cabrera (1989), Temperature effects on soil urease activity, Soil Biol. Biochem., 21, 935-938, doi:10.1016/ 0038-0717(89)90083-7.

Nason, G. E., D. J. Pluth, R. T. Hardin, and W. B. McGill (1990), Dynamics of foliar $\mathrm{N}$ in Douglas fir after spring and fall application of ammonium nitrate and urea, Can. J. For. Res., 20, 1515-1523, doi:10.1139/ x90-201.

Olsson, P., S. Linder, R. Giesler, and P. Högberg (2005), Fertilization of boreal forest reduces both autotrophic and heterotrophic soil respiration, Global Change Biol., 11, 1745-1753, doi:10.1111/j.13652486.2005.001033.x.

Prietzel, J., G. L. Wagoner, and R. B. Harrison (2004), Long-term effects of repeated urea fertilization in Douglas fir stands on forest floor nitrogen pools and nitrogen mineralization, For. Ecol. Manage., 193, 413-426, doi:10.1016/j.foreco.2004.02.006

Régnière, J., and R. St-Amant (2007), Stochastic simulation of daily air temperature and precipitation from monthly normals in North America north of Mexico, Int. J. Biometeorol., 51, 415-430, doi:10.1007/ s00484-006-0078-z.

Sitaula, B. K., L. R. Bakken, and G. Abrahamsen (1995a), N-fertilization and soil acidification effects on $\mathrm{N}_{2} \mathrm{O}$ and $\mathrm{CO}_{2}$ emission from temperate pine forest soil, Soil Biol. Biochem., 27, 1401-1408, doi:10.1016/00380717(95)00078-S 
Sitaula, B. K., L. R. Bakken, and G. Abrahamsen (1995b), Nutrient balance in Scots pine (pinus sylvestris 1.) forest. 3. Fluxes of $\mathrm{N}_{2} \mathrm{O}$ from lysimeter as influenced by nitrogen input, Water Air Soil Pollut., 85, 1155-1159, doi:10.1007/BF00477137.

Stark, J. M., and M. K. Firestone (1996), Kinetic characteristics of ammonium-oxidizer communities in a California oak woodland-annual grassland, Soil Biol. Biochem., 28, 1307-1317, doi:10.1016/S0038-0717(96) 00133-2.

Stegemoeller, K. A., and H. N. Chappell (1990), Growth response of unthinned and thinned Douglas-fir stands to single and multiple applications of nitrogen, Can. J. For. Res., 20, 343-349, doi:10.1139/x90-050.

Valinger, E. (1993), Effects of thinning and nitrogen fertilization on growth of Scots pine trees: Total annual biomass increment, needle efficiency, and above-ground allocation of biomass increment, Can. J. For. Res. 23, 1639-1644, doi:10.1139/x93-204.

Vlek, P. L. G., and M. F. Carter (1983), The effect of soil environment and fertilizer modifications on the rate of urea hydrolysis, Soil Sci., 136, 5663, doi:10.1097/00010694-198307000-00008.
Welke, S. E., and G. D. Hope (2005), Influences of stand composition and age on forest floor processes and chemistry in pure and mixed stands of Douglas fir and paper birch in interior British Columbia, For. Ecol. Manage., 219, 29-42, doi:10.1016/j.foreco.2005.08.040.

Yoshinari, T., R. Hynes, and R. Knowles (1977), Acetylene inhibition of nitrous oxide reduction and measurement of denitrification and nitrogen fixation in soil, Soil Biol. Biochem., 9, 177-183, doi:10.1016/0038-0717 (77)90072-4.

T. A. Black, C. Bruemmer, and R. S. Jassal, Biometeorology and Soil Physics Group, Faculty of Land and Food Systems, University of British Columbia, Vancouver, BC, V6T 1Z4, Canada.

R. F. Grant, Department of Renewable Resources, University of Alberta, 4-30 Earth Science Bldg., Edmonton, AB T6G 2E3, Canada. (robert. grant@ales.ualberta.ca) 